\title{
Genetic Regulation of Avian Testis Development
}

\author{
Martin Andres Estermann (D), Andrew Thomas Major (D) and Craig Allen Smith*(D) \\ Department of Anatomy and Developmental Biology, Monash Biomedicine Discovery Institute, \\ Monash University, Clayton, VIC 3800, Australia; martin.estermann@monash.edu (M.A.E.); \\ andrew.major@monash.edu (A.T.M.) \\ * Correspondence: craig.smith@monash.edu
}

check for updates

Citation: Estermann, M.A.; Major, A.T.; Smith, C.A. Genetic Regulation of Avian Testis Development. Genes 2021, 12, 1459. https://doi.org/ 10.3390/genes12091459

Academic Editors: Francisco Javier Barrionuevo Jimenez, Miguel Burgos and Rafael Jiménez

Received: 7 September 2021

Accepted: 16 September 2021

Published: 21 September 2021

Publisher's Note: MDPI stays neutral with regard to jurisdictional claims in published maps and institutional affiliations.

Copyright: (c) 2021 by the authors. Licensee MDPI, Basel, Switzerland. This article is an open access article distributed under the terms and conditions of the Creative Commons Attribution (CC BY) license (https:/ / creativecommons.org/licenses/by/ $4.0 /)$.

\begin{abstract}
As in other vertebrates, avian testes are the site of spermatogenesis and androgen production. The paired testes of birds differentiate during embryogenesis, first marked by the development of pre-Sertoli cells in the gonadal primordium and their condensation into seminiferous cords. Germ cells become enclosed in these cords and enter mitotic arrest, while steroidogenic Leydig cells subsequently differentiate around the cords. This review describes our current understanding of avian testis development at the cell biology and genetic levels. Most of this knowledge has come from studies on the chicken embryo, though other species are increasingly being examined. In chicken, testis development is governed by the Z-chromosome-linked DMRT1 gene, which directly or indirectly activates the male factors, HEMGN, SOX9 and AMH. Recent single cell RNA-seq has defined cell lineage specification during chicken testis development, while comparative studies point to deep conservation of avian testis formation. Lastly, we identify areas of future research on the genetics of avian testis development.
\end{abstract}

Keywords: chicken testis; sex determination; DMRT1; gonadal development; PAX2; SOX9; AMH

\section{Introduction}

The gonads are fundamental to reproduction in animals. Among vertebrates, gonadal morphology is deeply conserved, as expected for organs that are essential for propagation of the species. The testes of males harbour the male germline and they secrete androgens that contribute to masculinisation of the soma. Understanding the cell biology and genetics of testis formation during embryogenesis is important for improving knowledge in diverse areas, from human sexual development to livestock breeding and species conservation. This review focusses on testis development in birds. Most current knowledge of avian testis biology has come from studies in the chicken, an agriculturally important species and a long-standing developmental model organism. Understanding avian sexual development is important for the poultry industry, which seeks methods of producing single sex bird lines [1]. Only females are required by the egg industry, while males are preferred by the meat industry. Male hatchlings are typically culled by the layer industry because they do not lay eggs [2]. Understanding how sex is determined in the chicken will lead to new and innovative ways of modulating sex in poultry. Furthermore, the chicken embryo is an instructive model for gonadal development. Given the conservation of testis morphology, studies in the chicken embryo have shed light on human testis development and its disorders $[3,4]$. The chicken is particularly suited to rapid functional analysis of gonadal genes. Embryos can be accessed in ovo, genetically manipulated and gonadal phenotypes observed up to several days later [5-8].

This review firstly considers the genetic mechanism regulating gonadal sex determination in birds, with emphasis on the testis. We then outline the developmental processes involved in testis formation in the chicken model; establishment of the gonadal primordium, differentiation of the Sertoli cell lineage from supporting cell progenitors, and testicular differentiation. We describe the principle factors involved in chicken testicular morphogenesis, and the importance of the gene, DMRT1 (Doublesex and mab-3 Related Transcription 
factor 1). Testis formation in other avians is also considered. Lastly, future directions in the field of avian testis biology are considered.

\section{Avian Sex Determination}

All birds have a ZZ; ZW sex chromosome system, which dictates "sex determination" across tissues of the body. Male is the homogametic sex $(\mathrm{ZZ})$, while the female is heterogametic $(Z W)[9,10]$. In chicken and most other birds, the $Z$ and $W$ are well differentiated; the $\mathrm{Z}$ is a large chromosome and the $\mathrm{W}$ is a smaller degraded version of the $\mathrm{Z}$, with few bona fide genes [9,11-14]. Remarkably, the incidence of rare gynandromorphic chickens suggests that sex chromosomes have a direct effect upon sexual differentiation of the body, with a lesser role for hormonal signalling. Gynandromorphs are bilateral sex chimeras, male on one side of the body and female on the other. Such birds are rare, but they have been reported in chickens and some other birds $[15,16]$. In the few gynandromorphic chickens that have been described, the "male" side of the body is predominantly composed of ZZ cells, while the female side is predominantly ZW. The male side has large comb and wattle, legs spurs, male feathering and thicker breast muscle. The female side has smaller wattle, small or absent spurs, female feathering and lighter breast muscle [15]. The gonads of these birds reflect the relative proportions of $\mathrm{ZZ}$ or $\mathrm{ZW}$ cells; testes when $\mathrm{ZZ}$ cells are present, and ovaries when ZW cells are predominant [15,17]. Gynandromorphs are unlikely to be generated by aberrant endocrine signalling, because hormones would be expected to flow equally to both sides of the body. In their detailed analysis of three gynandromorphic chickens, Clinton and colleagues (2012) noted that gynandromorphs are best explained by direct genetic effects of the sex chromosomes in every cell, coining the term "Cell Autonomous Sex Identity" (CASI) [18]. This phenomenon is supported by manipulation of gonadal development in chicken embryos. When male Green Fluorescent Protein (GFP)labelled presumptive gonadal tissue is grafted into a non-GFP female recipient embryo at embryonic day 2 (stage 14), the labelled cells differentiate into Sertoli cells (the so-called male supporting cell lineage), despite being in an ovarian environment [15]. Similarly, when female GFP-labelled cells are grafted into a male embryo, the labelled cells followed their own endogenous female fate [15]. In the chicken gonad, this intrinsic "sex identity" appears to be specific to the supporting cells but not cells of the gonadal epithelium, as epithelial fate can be modulated by estrogen, resulting in a thickened gonadal cortex, the site of folliculogenesis [6]. In fact, estrogen is required early in avian gonadal development [19]. The estrogen-synthesising enzyme, Aromatase, is expressed in female but not male embryonic gonads, and is both necessary and sufficient for ovary formation [20-23]. During embryonic testis formation, Aromatase expression must be inhibited. Most recently, it has been shown that genetically male (ZZ) chickens with monoallelic deletion of the Z-linked gene DMRT1 develop ovaries instead of testes, but the rest of the body remains largely male [24]. This supports the concept of CASI, and it also confirms DMRT1 is the master chicken testis determinant (discussed further below).

Other sex-linked genes must underly CASI in different cells, as DMRT1 is not expressed beyond the gonads. In this regard, it is noteworthy that, unlike therian mammals, birds lack global $Z$ chromosome dosage compensation. As a result, on average, males (ZZ) have twice the level of Z-linked gene expression seen in females (ZW). This applies to various tissues tested in embryonic and adult chickens, and in other birds that have been examined [25-32]. Hence, different levels of different Z-linked genes may regulate sexually dimorphic anatomy in birds; the DMRT1 gene in the gonads, and other Z-linked genes in other tissues (or female-biased genes expressed from the W sex chromosome) [33]. Developmentally, it has been proposed that gynandromorphs may arise due to failure of polar body extrusion during meiosis in the ZW ovum, and subsequent fertilization of the $\mathrm{W}$ and $\mathrm{Z}$ pronuclei by two Z-bearing sperm. This rare event would produce to an embryo with ZW diploid cells on one side of the body and ZZ cells on the other side [15]. 


\section{Structure of the Adult Avian Testis}

Unlike in therian mammals, avian testes are located deep in the body cavity, and hence spermatogenesis progresses at a temperature at or slightly above $37^{\circ} \mathrm{C}$. In seasonal breeding birds, the testes increase dramatically in size, regulated via neuroendocrine response to photoperiod. In some species, testes increased in size by over $50 \%$ during the breeding season, controlled by the hypothalamic-pituitary axis [34]. The paired testes of adult birds comprise seminiferous tubules that house germ cells and supporting Sertoli cells, surrounded by steroidogenic Leydig cells. This is exemplified in the chicken Gallus gallus domesticus (Figure 1A) [35]. The avian testis grows substantially between hatching and sexual maturation, when semen is produced and birds copulate (up to 12 weeks of age) [36]. Prior to sexual maturation in the chicken, interstitial tissue (steroidogenic and mesenchymal cells) is extensive, while the seminiferous tubules comprise a single layer of cells along the basal lamina (Sertoli cells and pro-spermatogonia) [35]. The lumen is narrow or absent. As post-hatching development proceeds, there is a period of rapid cell proliferation within the tubules, such that they come to occupy a greater percentage of total testis volume. After this period of post-hatching proliferation, Sertoli cells become mitotically inactive and undergo maturation, characterized by a columnar shape, polarization and alignment along the basal lamina of the testis tubule [37]. In chicken and quail, this phase of Sertoli cells development is regulated by pituitary derived FSH and gonadal testosterone $[38,39]$. As in mammals, the post-embryonic Sertoli cells intimately surround the germ cells, generating an essential microenvironment for spermatogenesis. In the mature chicken, stages of spermatogenesis, ranging from spermatogonia to mature spermatozoa, are present in the mature tubules (Figure 1B) [35]. As in mammals, Sertoli cells are present around the germ cells, providing a niche for spermatogenesis via secreted signals. In the mature chicken testis, Sertoli cells express the marker, SOX9 (Figure 1C). Spermatogonia and Sertoli cells are arrayed along the basal lamina of the seminiferous tubule, as demarcated by nuclear DMRT1 immunofluorescence (Figure 1D). Mature chicken Sertoli cells and germ cells have been isolated and cultured in vitro for functional analysis and, in the case of germ cells, for the generation of genetically modified embryos and birds [40-46]. 

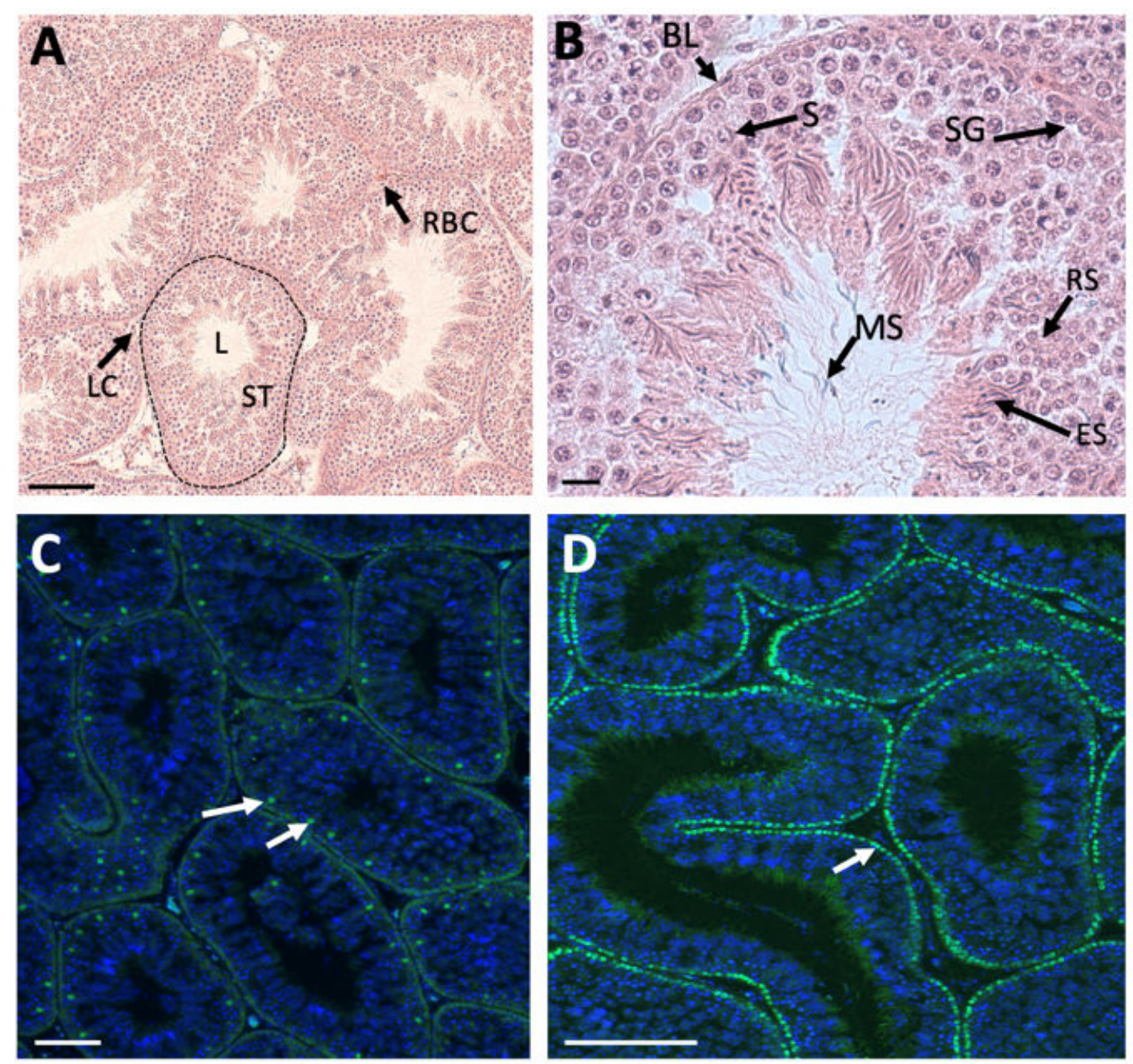

Figure 1. Histology and immunofluorescence of adult chicken testis. (A). Haematoxylin and eosin staining, showing seminiferous tubules (example: ST, dotted outline) and clusters of Leydig cells (example: LC). Red blood cells (RBC) are present between tubules. L, lumen of tubule. Scale bar $=100 \mu \mathrm{m}$. (B). High magnification view of adult testis tubule, showing Sertoli cells (example, S) and stages of spermatogenesis (example: SG, spermatogonia; RS, round spermatids; ES, elongated spermatids; BL, basal lamina; MS, mature spermatozoa). Scale bar $=10 \mu \mathrm{m}$. (C). Immunofluorescent localization of SOX9 (green) in the Sertoli cell nuclei of seminiferous tubules (example; white arrows). DAPI counterstain. Scale bar $=100 \mu \mathrm{m}$. (D). Immunofluorescent localization of DMRT1 in the nuclei of spermatogonia and Sertoli cells (green), aligned along the basal lamina of the seminiferous tubule (example, white arrow). DAPI counterstain. Scale bar $=100 \mu \mathrm{m}$.

\section{Embryonic Development of the Testis in the Chicken Model}

The chicken embryo is a widely used model of vertebrate embryogenesis. In the area of avian sex determination and gonadal sex differentiation, most of our knowledge has come from studies on the chicken embryo [3,47-50]. Figure 2A shows the histology of testicular morphogenesis in the chicken model. The total period of embryogenesis in the chicken is 21 days. As in mammals, the embryonic gonads are of mesodermal origin, forming on the ventromedial surface of the mesonephric kidneys. In chicken, the first histological sign of gonad formation is emergence of the genital ridge, a local thickening of the coelomic epithelium overlying the mesonephros and an accumulation of mesenchyme immediately beneath the epithelium [51]. This occurs between embryonic days (E) 3.5 and 4.5, corresponding to Hamilton and Hamburger $(\mathrm{HH})$ stages 21-25 [52]. Even earlier in development, at E2.0 $(\mathrm{HH})$ cell proliferation in the medial lateral plate mesoderm of the chicken embryo generates gonadal precursor cells via local Sonic Hedgehog action, mediated via BMP4 $[7,53]$. The gonads at this stage are considered "indifferent" or "bipotential", 
though their fate is already determined by their sex chromosome constitution ( $Z Z$ or $Z W)$. Up to E5.5 (stage 27), the undifferentiated gonad comprised the outer coelomic epithelium and underlying cords of cells (the so-called "medullary cords") interspersed with loose mesenchymal cells (Figure 2A). The left gonad (in both sexes) is somewhat larger than the right, and it accumulates a larger number of germ cells [50,54]. As development proceeds, this left-right gonadal asymmetry becomes very marked in females, but is reduced in males. Gonadal asymmetry is driven by left-biased action of the PITX2 gene in chicken. Early genetic markers of the gonad prior to sexual differentiation include the transcription factor, LHX1, and the signalling molecule, FGF9, expressed in the gonadal surface epithelium, and SF1 (Ad4BP) and PAX2, expressed in the underlying mesenchyme $[55,56]$. The transcription factor, GATA4, is expressed in the outer epithelium and underlying medulla. In the mouse model, FGF9 is required for proper testis formation, responding to the transcription factor, SOX9 [57,58]. In chicken, over-expression of FGF9 stimulates cell proliferation and produces an enlarged gonad [55]. At least some of this FGF9 derives from the adjacent mesonephric kidney in chicken [55]. As in mouse, LHX1 is also likely to be required for early somatic cell proliferation in the avian gonad. Steroidogenic factor 1 (SF1, or Ad4BP) is strongly expressed in the mesenchyme of the chicken gonadal (and adrenal) primordium. SF1, encoded by the gene Nr5a1 is essential for proper gonad and adrenal formation in mammals. Nr5a1 null mice show gonadal and adrenal agenesis [59]. However, SF1 has not been functionally analysed during avian gonadogenesis.

Sexually dimorphic gene expression is already apparent in morphologically undifferentiated chicken gonads at E4.5 (HH stage 25). This is primarily W-linked expression in females and elevated Z-linked expression in males due to incomplete dosage compensation $[12,60]$. There is currently no evidence that $W$-linked genes play a role in avian gonadal sex determination $[61,62]$. The $\mathrm{W}$ sex chromosome in chicken is a degenerate homologue of the $\mathrm{Z}$ chromosome, the latter carrying around 1000 genes. Those few bona fide genes present on the largely heterochromatic chicken $W$ are likely to be important genes that are dosage sensitive and have not been lost over evolution [12,63,64]. Most Z-linked genes are more highly expressed in males (ZZ) and they encode proteins with general metabolic and cellular maintenance functions, un-related to sex $[65,66]$. However, at least two Z-linked are expressed in the gonads and implicated in testis development in chicken, DMRT1 and HEMGN $[67,68]$.

By embryonic day 5 (HH stage 25) in chicken, the undifferentiated gonadal primordium comprises a distinct medulla and a columnar or pseudostratified outer surface (coelomic) epithelium (Figure 2A) [69,70]. (Then latter is also called the germinal epithelium.) Primordial germ cells (PGCs), having migrated from the germinal crescent via the blood stream [42], populate both medulla and gonadal surface epithelium (Figure 2A and B). The germ cells express DAZL and CVH (Vasa), both of which encode RNA-binding factors [71]. In the chicken, as in mammals, gonadal sex differentiation occurs during embryonic life and involves sexually dimorphic gene expression [3,50,72]. The first overt morphological sign of testis formation is the enlargement and proliferation of somatic cells in the medullary cords of the gonad (Figure 2A) [51,69]. These cells represent the pre-Sertoli cell lineage. These cells become organized in the medullary epithelial-like cords, they elaborate basement membrane and enclose PGCs. In the chicken embryo, this occurs from E6.0 (HH stage 30 -31) [73]. Outside these medullary cords, desmin and fibronectin positive mesenchymal cells give rise to interstitial cells [74], the site of later myoid and steroidogenic Leydig cell development. By E9 (HH stage 35), testis (seminiferous) cords are apparent, and loose mesenchymal cells are dispersed in the surrounding interstitium (Figure 2A). High magnification view of the developing chicken testis at this time point reveals Sertoli cells and PGCs within the testis cords (Figure 2B). As in mammals, Sertoli cells represent the first testicular lineage to differentiate in the chicken testis, expressing the markers DMRT1, AMH and SOX9 (Figure 2C,D) [3,75]. 


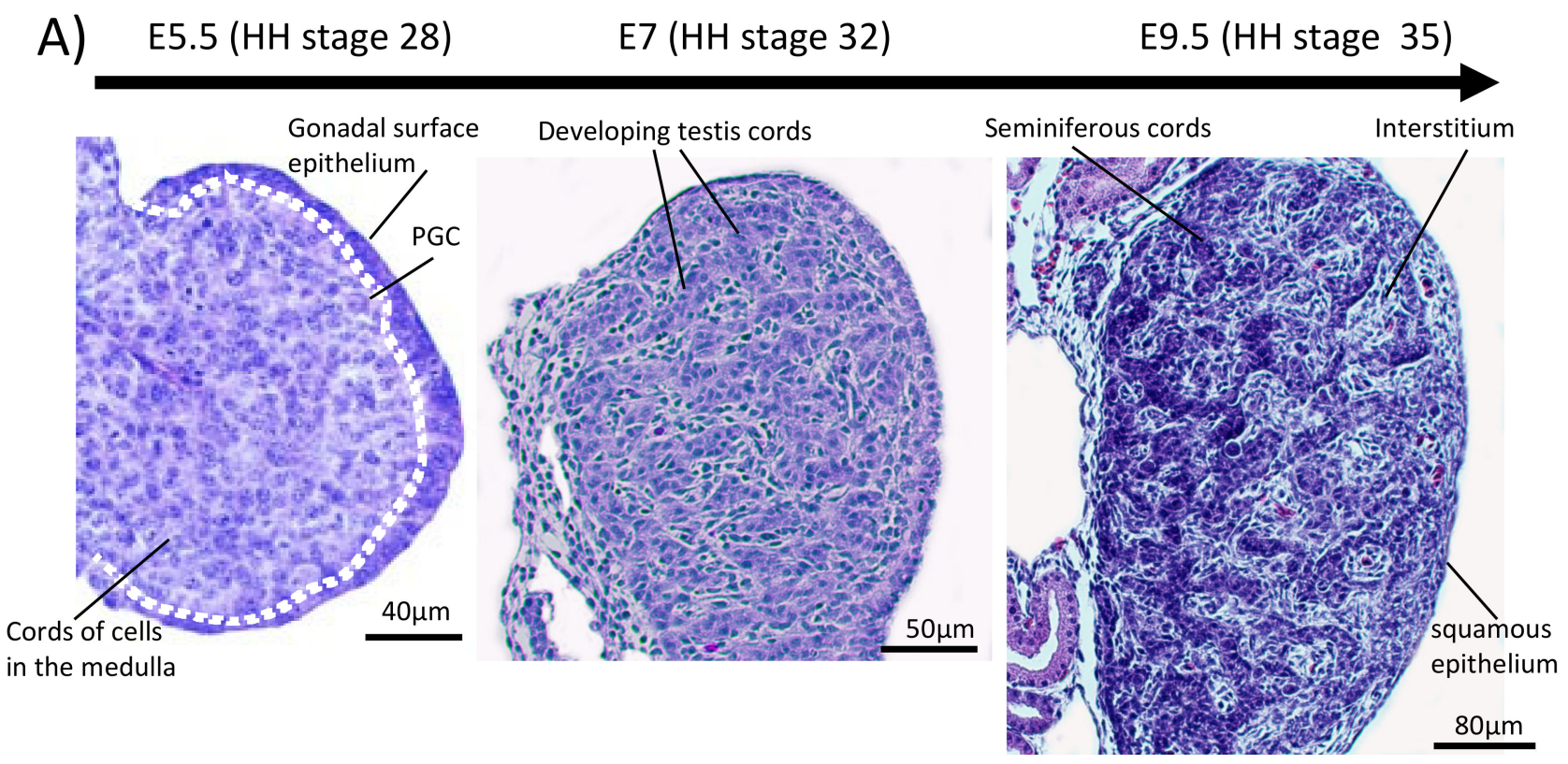

B) E9.5 Testis cords

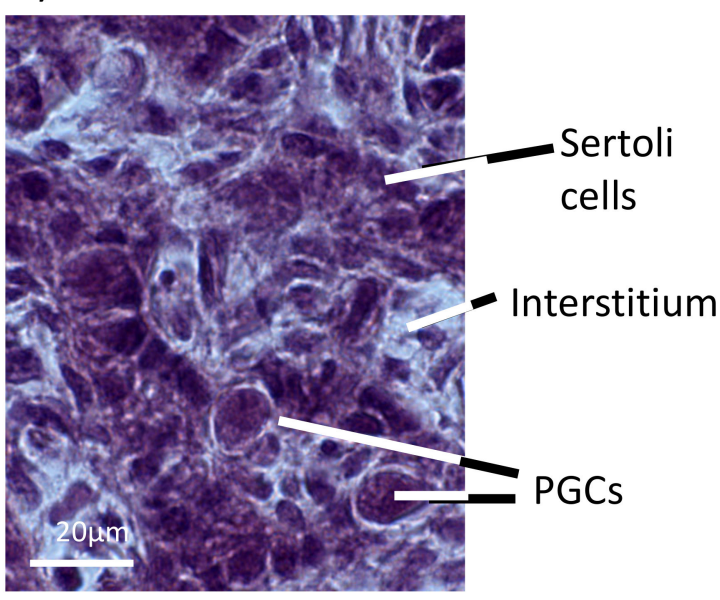

C) E7 DMRT1/AMH

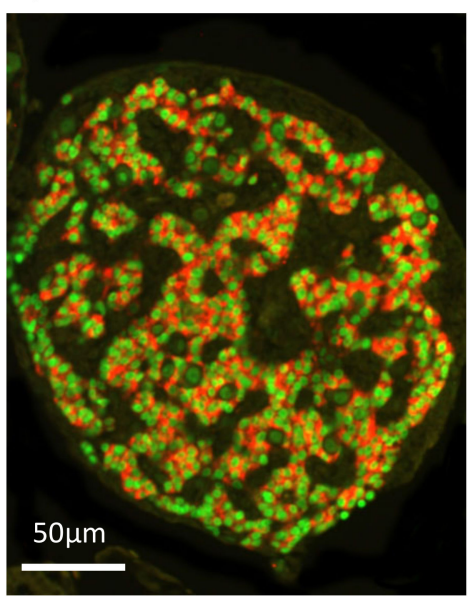

D) E7 SOX9

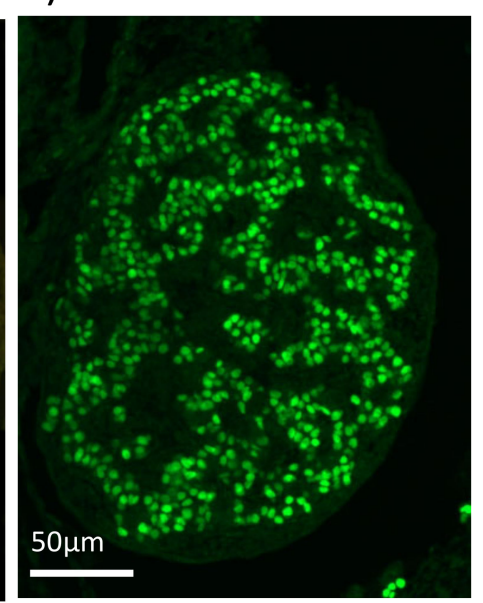

Figure 2. Testis development in the chicken embryo. (A) Histology of early testis differentiation, from E5.5 to E9.5. At E5.5, the gonad is morphologically undifferentiated, comprising outer epithelial cell layer and cords of cells in a dense underlying medulla. Dotted line demarcates the surface epithelium. Between E6.0 (stage 31) and E7.0 (stage 32), pre-Sertoli cells differentiate in the medulla, generating testis cords. By E9.5 (stage 35), Sertoli cells and primordial germ cells (PGCs) are apparent in testis (seminiferous) cords. The outer epithelium has become flattened, forming a squamous cell layer. (B) High magnification view of E9.5 (stage 35) testis cords, showing Sertoli cells, PGCs and surrounding mesenchymal cells in the interstitium. (C) Expression of the Sertoli cell markers, DMRT1 (green) and AMH (red) in the developing testis cords at E7 (stage 32). (D) Expression of the Sertoli cell marker, SOX9 (green) in the nuclei of Sertoli cells at E7 (stage 35).

The chicken gonad develops in close association with the mesonephric kidney (mesonephros). The contribution of the mesonephros to chicken gonad formation has been debated. In the mouse, lineage tracing and single cell RNA-sequencing have shown that cells derived from the mesonephros contribute to the interstitial steroidogenic and vascular lineages on the developing testis [76,77] (reviewed in [78]). In contrast, the key supporting cell lineage (Sertoli cells in the testis, pre-granulosa cells in ovary) derives from the coelomic epithelium in the mouse [79-81]. An intact mesonephros is apparently not required for chicken gonadal development; early ablation of the mesonephros does not 
perturb gonadal development and sexual differentiation, although gonads are smaller than normal $[82,83]$. However, mesonephric ablation in the chick still leaves a pool of nephrogenic mesenchyme, which can contribute to the gonad.

\section{Molecular Regulation of Avian Testis Formation and the Role of DMRT1}

Most current knowledge of avian testis development has come from studies on the chicken embryo $[5,84,85]$. In contrast to the mouse, the key supporting cell lineage does not arise from the coelomic epithelium in the chicken embryo. Lineage tracing and single cell RNA-seq in the chicken have shown that the gonadal surface epithelium (coelomic epithelium) generates non-steroidogenic interstitial cells, while the supporting cells (Sertoli cells in the testis, pre-granulosa cells in the ovary) derive from nephrogenic mesenchyme $[5,86]$. In both sexes, single cell RNA-seq identifies the gonadal mesenchymal supporting cell progenitors as a population expressing the transcription factors, $P A X 2$, OSR1, and DMRT1 together with the WNT4 signalling molecule (Figure 3) [86]. PAX2 is a Paired Box homeodomain protein. It has not previously been linked to vertebrate gonadal development, but we find that it is expressed in the gonadal medulla of the undifferentiated chicken gonad, with expression being down-regulated as the gonads commence sexual differentiation [86]. OSR1 (Odd-Skipped Related Transcription Factor 1) is required for early specification of the urogenital system [87-89], but a later role in gonadal development per se has not been reported. In the chicken, OSR1 expression is maintained in the female supporting cell lineage (pre-granulosa cells of the medulla) but expression declines in the testis. Similarly, WNT4 expression is maintained in the developing chicken ovary, but is down-regulated during testicular morphogenesis $[86,90]$. Of these four diagnostic factors expressed in the indifferent embryonic chicken gonad, DMRT1 expression is maintained at a high level in males, and is more lowly expressed in females. DMRT1 encodes a zinc finger-like transcription factor with a DNA-binding DM domain. This gene is now proven to be the master genetic trigger for testis formation in the chicken [24,67], and likely in all birds [61]. A recent comparative study conducted in our lab found that PAX2 and $D M R T 1$ exhibit conserved expression in the embryonic gonads of Japanese quail (Coturnix japonica), zebra finch (Taeniopygia guttata) and emu (Dromaius novaehollandiae). These species represent each of the major clades of avians (Galliformes, Neoaves and Paleaognaths) (Estermann et al. in press). In each species, PAX2 expression is extinguished as DMRT1 expression is activated. As in chicken, DMRT1 is more highly expressed in male vs female gonads in quail, finch and emu.

Elevated DMRT1 expression in ZZ chicken embryos operates as the genetic switch for testis formation. The DMRT1 gene is a deeply conserved among vertebrates, with a conserved role in testis development and function across all major clades [91-94]. In the mouse, DMRT1 is required to maintain the postnatal Sertoli cell phenotype, and for regulating gametogenesis [95-99]. DMRT1 is required for testis development in turtles with either "genotypic" or temperature-dependent sex determination [100-102]. Furthermore, $D M R T 1$ or paralogous genes are required for gonadal development in amphibians and fishes [103-108]. In these groups, DMRT1 may act as primary testis-determining switch (e.g., some fishes and reptiles) or as a downstream player in Sertoli cell development and maintenance (e.g., mouse). In birds, DMRT1 is located on the $\mathrm{Z}$ sex chromosome, present in two copies in males (ZZ) and in one copy in females (ZW) [109]. This chromosomal location makes the gene a prime candidate master regulator of gonadal sex determination. The avian Z sex chromosome is deeply conserved and Z-linkage of DMRT1 applies to all birds analysed, even the phylogenetically distinct flightless ratites. In emu and ostrich, the sex chromosomes are poorly differentiated and they exhibit extensive meiotic crossing-over, but, significantly, not in the region harboring Z-linked DMRT1 [10,110,111]. 


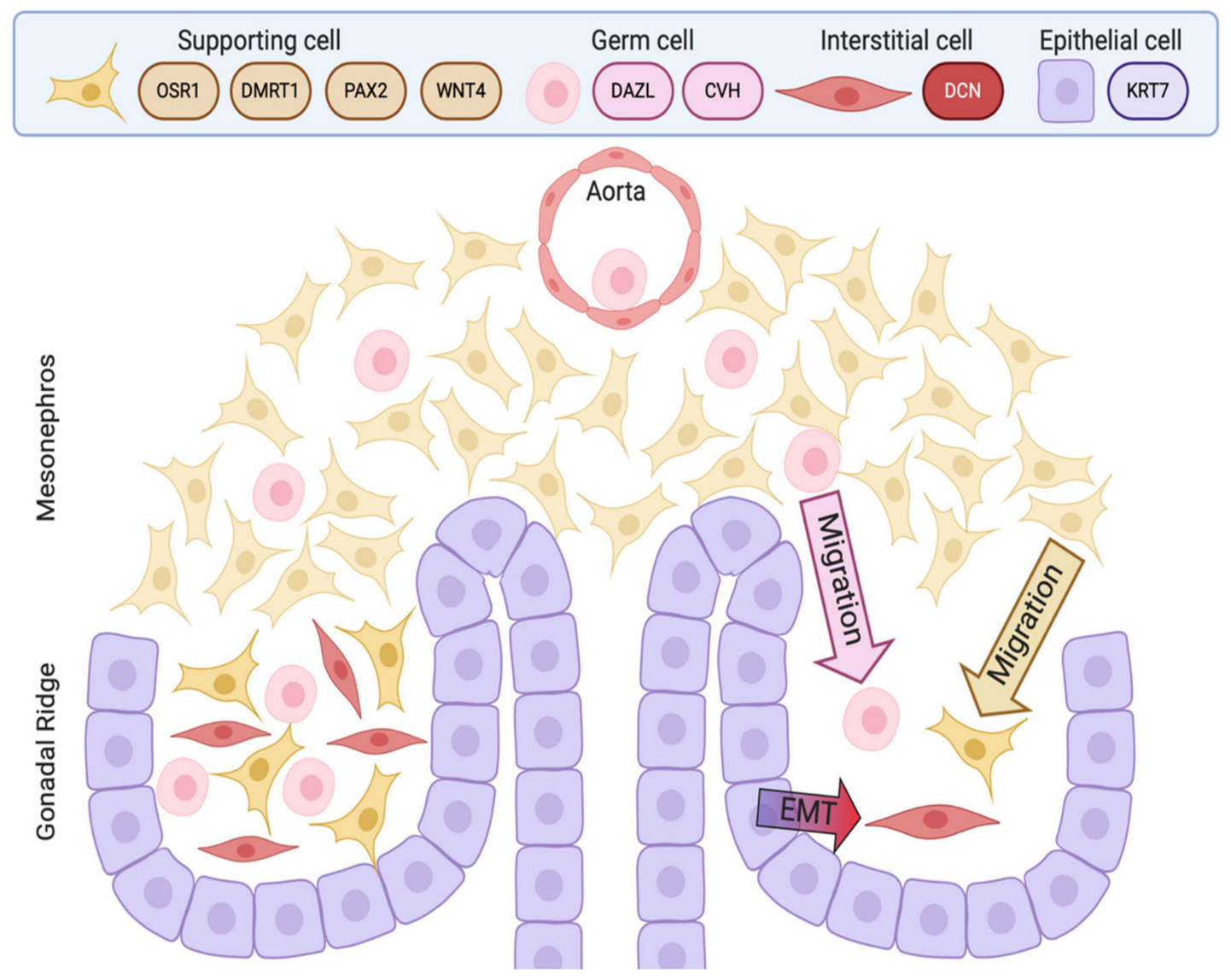

Figure 3. Schematic view of paired gonadal primordia development in the chicken embryo (E3.5- E4.5/stage 19-25). The supporting cell lineage (pre-Sertoli cells in males) derives from a resident mesenchymal cell population expressing PAX2, OSR1, WNT4 and DMRT1 (brown). The DAZL/CVH+ germ cells (pink) migrate into the gonad via the blood stream, exiting the dorsal aorta. The Keratin 7+ (KRT7) gonadal surface epithelium (coelomic epithelium) (purple), generates Decorin + (DCN) non-steroidogenic interstitial cells (red) via an Epithelial to Mesenchyme Transition (EMT), at least at early embryonic stages. image created with BioRender.

In embryonic chicken gonads, DMRT1 is expressed in the supporting cell lineage of both sexes (pre-Sertoli cells in males and fetal pre-granulosa cell progenitors in females). However, it is always more highly expressed in males, reflecting the lack of global $\mathrm{Z}$ inactivation [112-114]. This initial two-fold difference in DMRT1 expression between the sexes is sufficient to drive testis as opposed to ovary formation. Knockdown of DMRT1 in ZZ chicken embryos using virally delivered short hairpin RNAs results in feminization of the gonads, with down-regulation of $S O X 9$ and $A M H$, and upregulation of the ovarian markers, FOXL2 and Aromatase [67]. Conversely, mis-expression of DMRT1 in ZW gonads by in ovo electroporation results in ectopic activation of SOX9 and $A M H$, and disruption of Aromatase expression [75]. Most recently, CRISPR/Cas9 genome editing was used to delete one copy of DMRT1 in the chicken, causing ZZ birds to develop feminised gonads or ovaries. Two different studies have been reported. Ioannidis and colleagues used single stranded oligonucleotides (ssODNs) to introduce a loss-of-function mutation and monoallelic inactivation of DMRT1. This resulted in clear ovary development in genetically male (ZZ) birds (embryos and adults) [24]. Lee et al. used a Cas9-mediated NHEJ (NonHomologous End Joining) to generate a disrupted DMRT1 allele via GFP insertion. They found feminization but not complete ovary formation in $D M R T 1^{-/ Z}$ birds, perhaps due to some off-targeting effects [115]. Nevertheless, overall, current data confirm that DMRT1 is the master Z-linked genetic trigger for testis formation in the chicken [24,115]. Loss of $D M R T 1$ expression is dispensable for chicken ovary development, though oogenesis is 
impacted. Based on these studies, it is currently considered that elevated expression of $D M R T 1$ in ZZ avian embryos antagonizes the FOXL2-Aromatase axis in medullary cords, which otherwise results in estrogen synthesis and ovarian differentiation [24]. However, when one copy of DMRT1 is deleted in ZZ birds, the rest of the body remains "male", with male type weight, comb and wattle, supporting the notion of cell autonomous sex identity, as discussed above [24].

Testis-enriched DMRT1 expression in conserved during gonadal development in other avian species. We have recently reported male up-regulation at the onset of gonadal sex differentiation in representatives of each major avian clades (Galliformes, Neoaves and Palaeognaths). As in the chicken, DMRT1 is male up-regulated during embryonic gonadal development in all other avians examined, including diverse species such as the Japanese quail, zebra finch and emu, (Estermann et al., in press) [61]. The same applies to embryonic development of the gonads in the Muscovy duck [116]. These data strongly indicate that Z-linked DMRT1 is the master regulator of testis formation across all birds, in line with its deep conservation and role in the testis of other animals. In birds, DMRT1 may have been one of the first genes to become differentially expressed between the sexes early in the evolution of the $\mathrm{Z}$ and $\mathrm{W}$ sex chromosomes. It is expected that other male-specific genes have also been recruited and enriched on the avian Z [117,118], in light of the CASI concept. Through the analysis of 5' regulatory regions, it has been proposed that DMRT1 first played a role in germ cell development in vertebrates (fishes), but then became recruited to the somatic cells of the gonads, where it acquired a role in Sertoli cell specification as well [107]. This would apply to birds and reptiles, but in mammals, the early role of DMRT1 has been supplanted by the Y-chromosome-linked $S R Y$ gene, at least among eutherians.

In the embryonic chicken gonad, DMRT1 is also expressed in the germline. Nuclear expression of the protein can be detected in chicken primordial germ cells from early stages of gonadal sex differentiation [119]. Its role in avian germ cells has not been fully explored, but it may play a role in directing male germ cell differentiation, from mitotic arrest to specification of spermatogonia. In the mouse, DMRT1 plays multiple crucial roles in germ cell differentiation, in both sexes [92,120,121]. In the testis, it promotes mitotic arrest and suppresses pluripotency genes at embryonic stages and, in certain strains, is a tumor suppressor [122,123]. Postnatally, DMRT1 is required in the mouse for resumption of germ cell mitosis, migration to the germ cell niche and survival of spermatogonia $[95,98]$. At adult stages in mouse, DMRT1 regulates entry into meiosis [124]. It is likely that DMRT1 has a comparable function in the avian germline. In chicken embryos that have been CRISPR/Cas9 edited to delete DMRT1, germ cells are present at embryonic stages and they populate the developing gonads as normal, but postnatal gametogenesis is disrupted [24].

\section{The Sertoli Cell the Lineage: Genes Downstream of DMRT1}

While the genetic trigger for testis formation differs among vertebrates, the downstream genetic hierarchy is at least partly conserved [125]. In birds, DMRT1 engages the testis developmental pathway during early embryogenesis. Figure 4 show the temporal expression pattern of DMRT1 together with other key testicular proteins, SOX9, AMH and Z-linked HEMOGEN (HEMGN). DMRT1 is expressed first, from at least as early as E4.5 (stage 25). HEMGN is subsequently detected, at varying levels across cells, from E5.5 (stage 28), together with SOX9, which is more homogenously expressed. This is followed by $A M H$ protein expression (Figure 4). SOX9 is a central hub gene required for the initiation of pre-Sertoli cell development in the gonadal medulla. SOX9 is a SOX box transcription factor in the same family as SRY. In mouse or human, the SOX9 gene is activated by the concerted action of SRY and SF1, which bind the SOX9 regulatory region [126-130]. In chicken, quail and duck, SOX9 is male-up-regulated during testis formation [131-133]. Indirect evidence indicates that DMRT1 activates SOX9 during pre-Sertoli cell specification. SOX9 expression is down-regulated following DMRT1 knockdown in male gonads (ZZ), and is ectopically activated when DMRT1 is mis-expressed in female gonads $(Z W)[24,67,75]$. As in other vertebrates, this is likely to trigger the differentiation of somatic medullary cord cells into 
the pre-Sertoli cell lineage [134]. In mammals, one of the principal targets of SOX9 is $A M H$, a diagnostic Sertoli cell glycoprotein responsible for Müllerian duct regression [135]. Accordingly, SOX9 transcripts are first detected prior to $A M H$ transcripts in the mouse embryo. However, the chicken is notably different; $A M H$ mRNA is first expressed prior to SOX9 mRNA (E4.5 vs E6.5), and in both sexes, though always more highly expressed in males $[85,136,137]$. ( $A M H$ is also expressed in female chicken because the right Müllerian duct also regresses, in line with regression of the right female gonad.) The data indicate that SOX9 does not activate $A M H$ gene expression in the avian model, although it may maintain it. $A M H$ may be activated by DMRT1, as $A M H$ expression declines following $D M R T 1$ knockdown, though direct evidence is lacking. Another possibility is that, while $A M H$ transcription is initiated prior to that of $S O X 9$, its translation into protein may be delayed, occurring after that of $S O X 9$, as suggested by the immunofluorescence shown in Figure 4 .

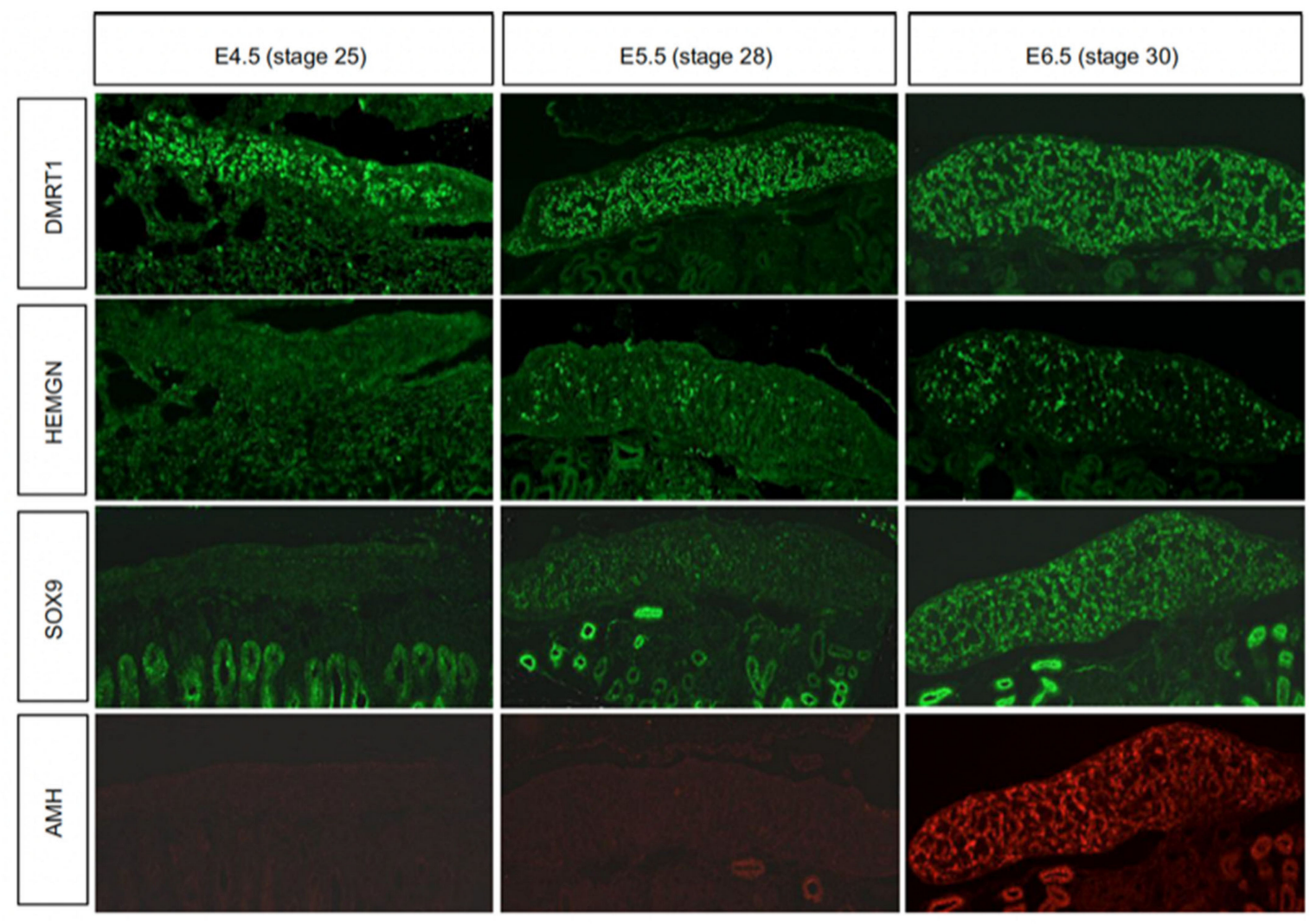

Figure 4. Chronology of marker protein expression in embryonic male chicken gonads at the onset of sexual differentiation.Immunofluorescence staining for DMRT1 (green), HEMGN (green), SOX9 (green) and AMH (red) proteins in E4.5 (HH25), E5.5 (HH28) and E.6.5 (HH30) embryonic gonads. DMRT1 shows robust expression from at least as early as E4.5. Both HEMGN and SOX9 are expressed from E.5.5 (stage 28), and AMH protein is detectable at E6.5 (stage 30-31). Scale bar $=100 \mu \mathrm{m}$. Reproduced from Lambeth et al., (2014) with permission.

Testis formation in the avian model may primarily depend upon the activation of SOX9 by DMRT1, with SOX9 then setting in motion the male genetic circuitry and repressing the female pathway. This would be analogous to the transient yet essential role of Sry in activating $S O X 9$ in the mouse. Some known targets of $S O X 9$ in the gonad that are required for proper testis development in the mouse embryo also apply to chicken. One of these is Prostaglandin D synthase (PDG2), activated by SOX9 in mouse. This enzyme produces Prostaglandin D2, which is required for feedback amplification of SOX9 transcription, and the recruitment and organization of Sertoli cell progenitors [138-140]. PGD2 is also expressed male-specifically in the embryonic chicken gonad and can up-regulate $S O X 9$, at 
least in gonadal explants [141]. Another well-established target of SOX9 in mouse is FGF9, which is required for proper Sertoli cell development and testis formation [57]. Activation of FGF9 by SOX9 also involves a positive feedback mechanism, whereby FGF9 binding to Fgfr2 is required for sustained SOX9 expression in mouse Sertoli cells and for their proliferation [58,142-145]. In mouse, FGF9 (masculinizing) antagonizes Wnt4 (feminizing) [58]. Our global and single cell RNA-seq studies have not identified FGF9 as a male up-regulated factor in embryonic chicken gonad, although other FGFs are expressed [12,86].

Comparative SOX9 ChIP-seq analysis has been performed on mouse and chicken embryonic gonads [146]. In the chicken, over 1000 enriched SOX9 ChIP peaks were identified from E7 (stage 32) male gonads, with some 263 genes are shared with those in an RNA-seq dataset [146]. Intriguingly, this study found only one SOX9 target gene shared between mouse and chicken-AMH. This suggests that the Sertoli cell gene regulatory network activated by SOX9 may differ between the two species. ChIP-seq for direct transcriptional targets of SOX 9 has been performed on embryonic mouse and bovine gonads. In that study, a conserved so-called "Sertoli cell signature" was identified, comprising genomic regulatory region motifs that bound SOX9, DMRT1 and the transcription factor GATA4 [147]. SOX9 in mouse and cow was found to exhibit direct transcriptional activation of target genes, and also sex-specific splicing of target transcripts. Among the conserved transcriptional targets included $A M H$ and FGF9, as expected, SOX9 itself and other SOX genes, WNTs, BMPs and FOXL2 (putative negative regulation for the latter). This data points to co-regulation of target genes by SOX9 acting together with DMRT1. It was reported in this study that the Sertoli cell signature of DMRT1-SOX9-GATA motif enrichment conserved in mice and cattle also occurs across the orthologous genomic regions of other mammals and indeed in chicken [147].

The direct transcriptional targets of DMRT1 during avian testis development are currently unknown. In mouse, genome wide analysis of DMRT1 targets has been examined using combined CHIP-seq and RNA expression analysis of juvenile testes. Some 1400 proximal promoter regions are bound by mouse DMRT1, including the DMRT1 gene itself. Mouse DMRT1 protein is bifunctional, acting as an activator or repressor [148]. GO term enrichment showed DMRT1 target genes encoding MAP kinases, FGF and IGFs, nuclear hormone receptors, cell cycle regulators and metalloproteinase factors, and other DM domain genes [148]. DMRT1, and other DM domain proteins, can function as heterodimers, and a core mouse DMRT1 consensus binding site has been identified $\left(\mathrm{ACA}^{\mathrm{A}} / \mathrm{T}\right.$ $\mathrm{TGT}^{\mathrm{T}} / \mathrm{A}$ ) [149]. These findings may also be applicable in chicken, but empirical DMRT1ChIP experiments have not yet been reported for birds. In their study of DMRT1-edited chicken embryos, Lee and colleagues used RNA-seq of knock out gonads compared to wild type gonads to identify global DMRT1 targets (direct or indirect). They found modules of genes which showed expression changes in E6 embryos and in one week old hatchlings after monoallelic deletion of DMRT1, many of which were Z-linked, and some of which specified long non-coding RNAs [115]. Some genes showed a direct "linear" relationship to changes in DMRT1 expression level, while other genes differentially expressed between the sexes responded differently to DMRT1 loss. Some 213 genes did not change after DMRT1 deletion, but were still sexually dimorphic in wild type gonads, suggesting that some gonadal sex-determining pathways may be independent of DMRT1. It would be worthwhile to compare the RNA-seq datasets derived from DMRT1-edited embryos [115] with the chicken SOX9 ChIP dataset [147] to determine whether DMRT1 and SOX9 co-regulate a suite of target genes in chicken, as uncovered in mammals. As in mammals, DMRT1 is thought to have a dual role in birds, promoting testis development in male (ZZ) embryos and repressing ovarian development in ZW (female embryos). The DMRT1 protein is therefore likely to act as a transcriptional activator and a transcriptional repressor in the embryonic avian gonad. Consistent with this idea, mis-expression the gene in female gonads induces SOX9, HEMGN and AMH and represses Aromatase expression [75], while monoallelic deletion induces the converse [24]. 
HEMOGN has been shown to play a role in embryonic chicken testis development. This gene encodes a nuclear-localized transcription factor with a role in modulating hematopoiesis [150]. An expression-based screen revealed HEMGN to be expressed in male but not female embryonic chicken gonad, and in the key Sertoli cell lineage [68]. Like DMRT1, HEMGN is Z-linked in chicken, though its expression is initiated after that of DMRT1, as shown in Figure $4[68,75]$. Over-expression of DMRT1 in embryonic female chicken gonads can induce HEMGN expression, further implying that it lies downstream of DMRT1 [75]. Over-expression of HEMGN in female gonads can induce masculinization, with ectopic SOX9 expression and repression of the female markers, FOXL2 and Aromatase [68]. Interestingly, this experiment also up-regulates DMRT1, implying a positive feedback relationship between the two factors. Targeted knockdown or knockout of HEMGN has not been reported. However, curiously, HEMGN expression has not been detected in the embryonic gonads of other avians, such as zebra finch and emu [61]. The role of HEMGN in differentiation of the Sertoli cell lineage could be chicken (or Galliform)-specific.

\section{Chicken Sertoli Cell Differentiation Revealed by Single Cell RNA-Seq}

Most recently, single cell RNA-seq (scRNA-seq) has been used to provide insight into the gene regulatory network activated by DMRT1 and the induction of cell lineage specification. Compared to females (ZW), higher expression of DMRT1 in males (ZZ) induces rapid upregulation of thousands of genes that results in the differentiation of Sertoli cells, including known factors such as $A M H$ and SOX9, and previously unknown factors [86]. The scRNA-seq indicates that in addition to these "typical" Sertoli cells, expressing higher levels of DMRT1, SOX9 and AMH, a second type of Sertoli cells was identified in embryonic chicken testis. These "type 2" Sertoli cell express the same markers as typical Sertoli cells, but in lower levels [86]. At E10.5, these two populations appear in different testicular regions. The typical Sertoli cells are in the basal testicular cords, whereas the type 2 cells localize in the peripheral testicular cords. The type 2 Sertoli cells express low levels of mitochondrial genes and high levels of GSTA2 and CBR4 (Figure 5) [86]. These differences point to a metabolic difference among Sertoli cell types. Interestingly, stem cells tend to rely on glycolytic metabolism rather than mitochondrial oxidative respiration [151], suggesting that the type 2 cells could be a stem-like population of Sertoli cells. The two cell types may represent two maturational states of Sertoli cells. The apical supporting cells are the first to up-regulate Sertoli cell markers such as $A M H$ and SOX9, suggesting an apical-basal wave of differentiation. Hence, this may reflect distinctive stages of Sertoli cell maturation, one more mature than the other. Further research is required to explore this dichotomy further.
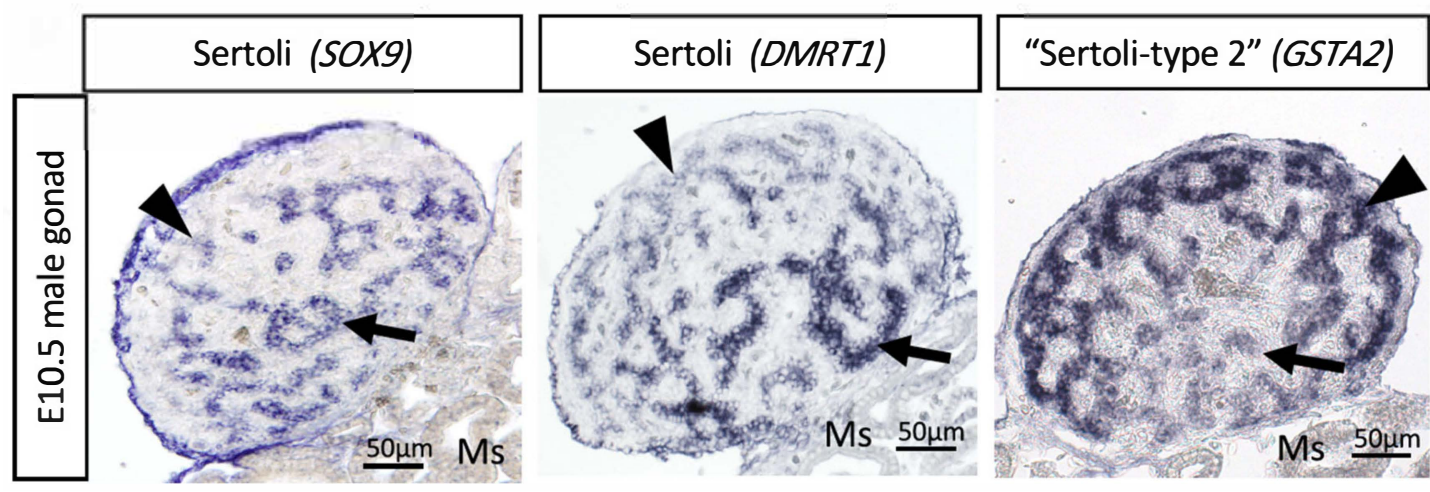

Figure 5. Marker gene expression in E10.5 (stage 35) embryonic chicken testis identifies two Sertoli cell populations. The first is more basally located and highly expresses SOX9 and DMRT1 and lower level GSTA2 (arrows). The second ("type 2" Sertoli cells) is more peripherally located and highly expresses GSTA2 but shows lower levels of DMRT1 and SOX9 expression. (Ms = mesonephric kidney). Reproduced form Estermann et al. (2020) with permission. 


\section{Interstitial and Steroidogenic Cell Differentiation}

The supporting cell population is the first cell lineage to differentiate in the embryonic gonads of vertebrates such as mammals and birds. In males, these cells form Sertoli cells. Signalling from Sertoli cells is thought to then direct the other uncommitted cells down the testicular developmental pathway [152,153]. In mouse, such signals include Desert Hedgehog (Dhh), important for fetal steroidogenic Leydig cell, germline development and peritubular myoid cell differentiation [154-157], and PDGF signaling involved in endothelial cell migration from the mesonephros. The latter is required for proper seminiferous cord partitioning in mouse $[77,158]$. Male-specific immigration of these endothelial cell precursors in mouse is also observed in chicken and also involves PDGF signalling [159]. Migrating endothelial cells form a testis-specific coelomic blood vessel in the mouse, a process blocked by factors such as Wnt 4 and follistatin in the developing ovary $[160,161]$. Although male-specific cell endothelial cell migration is also observed in the avian model (chicken) [159], no male specific blood vessel has been observed. Early morphological studies conducted in the 1950's showed that vascularisation of the embryonic chicken gonad in both sexes commences from E5 (stage 28) [162]. In terms of DHH singaling, expression of this factor has not been detected in the embryonic chicken testis [12,86], at least up to E10.5. Hence some of the Sertoli-derived signals may differ between mammals and birds.

Differentiation of the steroidogenic cell population (Leydig cells) is a critical step in testicular morphogenesis, being essential for androgen production and masculinisation. Histologically, fibroblastic-like Leydig cells containing lipid vesicles are first recognised in the chicken embryo at E8 (stage 32) [163], after the onset of Sertoli cell development and testis cord organisation. This also applies to other avians that have been examined, such as quail and ostrich $[164,165]$. The origin of Leydig cells appears to differ between the mouse and chicken models. In the mouse embryo, the steroidogenic lineage (fetal Leydig cells) largely derives from the same progenitor pool of coelomic epithelial cells that also gives rise to the pre-Sertoli cell lineage [80,81]. The latter has an Sry/SOX9/Wt1/DMRT1/Gata4 molecular signature, while the Leydig precursors have a Wt1/Gata4/Sf1 signature that features down-regulation of Wt1 [78,166,167]. A second source of fetal Leydig cells in mouse is the mesonephric kidney, a population that appears not to be induced by Hedgehog signalling [168]. However, in the chicken model, single cell RNA-seq suggests that the steroidogenic lineage derives directly from the differentiating supporting cell lineage (Sertoli cells in males and the medullary cord/embryonic pre-granulosa cells in females) [86, 169]. In the male chicken embryo, Sertoli cells are marked by expression of DMRT, SOX9 and $A M H$. Between E6.5 and E10.5, steroidogenic embryonic Leydig cells appear to differentiate directly from a subset of Sertoli cells by a process that involves a sequential upregulation of steroidogenic markers (e.g., CYP17A1) and downregulation of Sertoli markers (Figure 6) [86]. At E8.5 (stage 34), three different cell populations are detected in the testis: Sertoli cells expressing $A M H$ but not $C Y P 17 A 1$, Leydig cells expressing CYP17A1 but not $A M H$ and a small number of transitioning cells expressing both $A M H$ and CYP17A1 (Figure 6) [86]. Furthermore, in chicken, other steroidogenic enzymes are expressed in Sertoli cells, most notably, $3 \beta-H S D$, suggesting that both supporting and steroidogenic cells play a role in the synthesis of androgens, at least during embryonic stages [170]. In the mouse, there is reciprocal cross-talk between the fetal Leydig and Sertoli cells, ensuring proper seminiferous cord form and function [171]. This is likely to also apply in the avian testis, though it has not been well explored. 


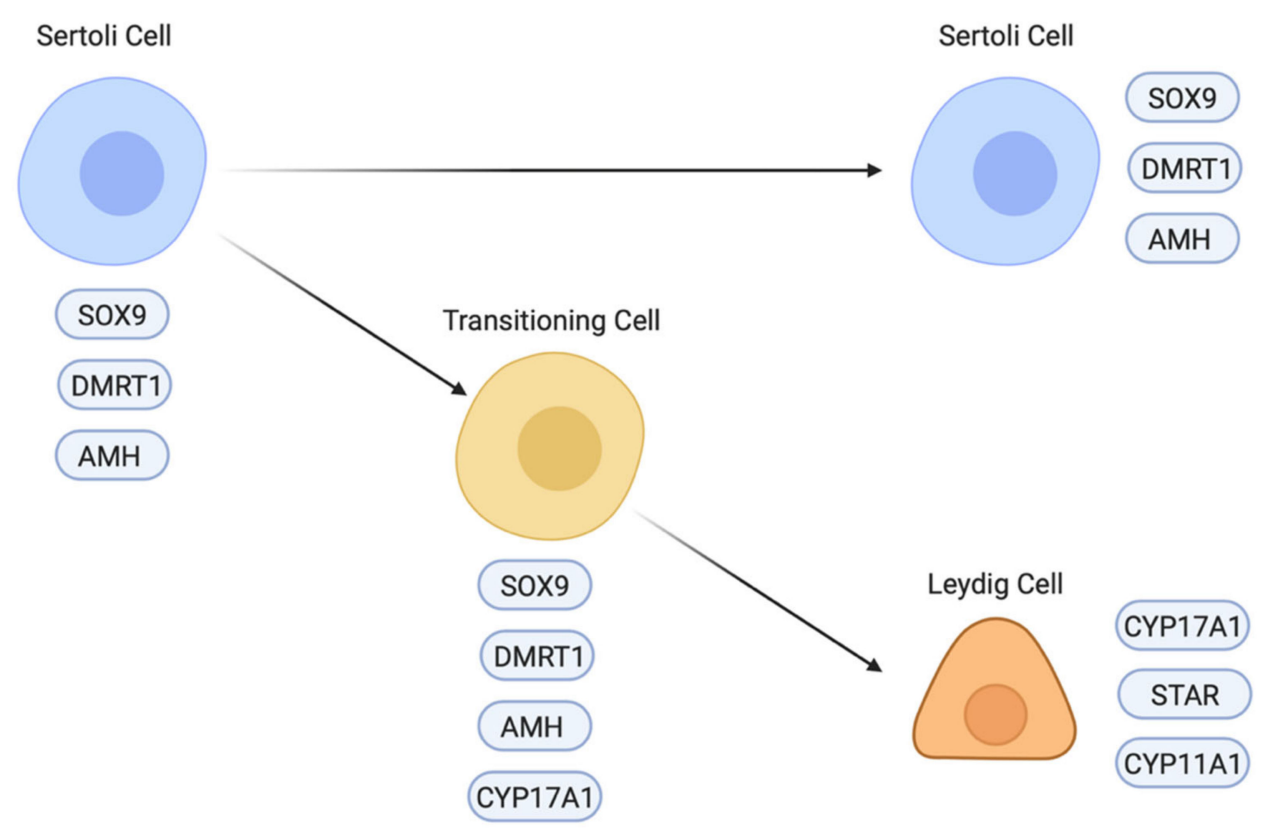

Figure 6. Leydig cells likely derive from a subpopulation of Sertoli cells in the chicken embryo. Some of the differentiated Sertoli cells (expressing SOX9, DMRT1 and AMH) start expressing the steroidogenic gene CYP17A1 and start transitioning into a steroidogenic cell type. These transitioning cells express both Sertoli and Leydig cell markers. In order to differentiate into Leydig cells, the Sertoli cell markers are downregulated and steroidogenic cell markers (StAR and CYP11A1, etc.) are upregulated. Image created with BioRender.com.

\section{Sex Steroid Synthesis and Testis Development}

In birds, estrogen production by the female gonadal medulla (embryonic pre-granulosa cells) is essential for proper ovary formation $[19,22,23,172,173]$. Aromatase enzyme, the rate-limiting factor in estrogen synthesis, is only expressed in female gonads at the onset of gonadal sex differentiation [21]. Evidence indicates that one of the main functions on $D M R T 1$ in genetic males is repression of aromatase expression, possibly via antagonism of the FOXL2 transcription factor [67]. However, a role for androgens in avian testis development, comparable to the role for estrogens for ovary development, is not apparent. Histochemical and endocrine assays conducted in the 1970's and 1980's indicated that the gonads of both sexes are steroidogenically active early, before the onset of gonadal sex differentiation. Based on early immunohistochemical studies, gonadal testosterone is first detectable prior to sexual differentiation, (as early as E3.5 (stage 19) in both sexes, becoming higher in ZZ males after E5.5 [174]. However, exogenously added testosterone does not masculinise embryonic chicken gonads [175].

More recent approaches such as RNA in situ hybridisation and RNA-seq have shown that the embryonic chicken testis expresses all enzymes required for testosterone synthesis from cholesterol (CYP11A2, HSD3 $\beta 1, C Y P 17 A 1$ and HSD17 $\beta 4)$ from the early stages of gonadal sex differentiation (at least as early as E6/stage 31) [12,20]. Based on one immunofluorescence and radioimmunoassay report, plasma testosterone was detected at E5.5 (stage 28) in the chicken, becoming higher in males from E7.5 (stage 32) [176]. However, some other studies using ELISA or immunoassay do not find sex differences in plasma testosterone levels at embryonic stages $[177,178]$. In females, androgen provides the substrate for aromatization and estrogen production when expression of CYP19A1 (encoding aromatase) commences at E6/ stage 30. However, as noted above, there is no evidence that testosterone plays a decisive role in avian testicular morphogenesis [175]. Gonads in the chicken appear to come under pituitary regulation in the latter part of embryogenesis, when the hypothalamic-pituitary-gonadal axis is established (from E11-13) [179-181]. 
Prior to this time, chicken gonadal sex differentiation appears independent of pituitary gonadotrophins, based on hypophysectomy data [180,182].

\section{Germ Cells in the Embryonic Chicken Testis}

The primary role of the gonads is to facilitate gametogenesis [183]. As the somatic cells differentiate into distinct testicular or ovarian cell types during embryogenesis, the primordial germ cells (PGCs) are exposed to sex-specific signalling that affects their fate [184]. PGCs of the developing testis become enclosed in seminiferous cords, a conserved process seen in essentially all vertebrates. In mammals, a critical difference between testicular and ovarian germ cells is the timing of meiotic entry. While male germ cells remain arrested in mitosis during embryogenesis, female germ cells enter in meiosis, arresting in diplotene of meiosis I. In the mammalian embryo, several lines of evidence indicate that retinoic acid (RA) diffusing from the mesonephros induces germ cells to enter in meiosis in females [185,186], though this has recently been questioned [187,188]. In males, CYP26B1 enzyme expressed in Sertoli cells is thought to degrade retinoic acid (RA), creating a physical barrier to meiosis in the adjacent PGCs [189]. Instead, spermatogonia are arrested in G1/G0 and do not enter meiosis until after birth. RA can also antagonise somatic development in the mouse testis, as Cyp26b1 null mouse mutants have impaired steroidogenesis and mild ovotestis development [190]. In the chicken and other avians, PGCs arise at the anterior margin of the area pellucida, and in vitro data indicate that specification involves BMP4 [191]. The PGCs migrate through the germinal crescent and bloodstream to populate the gonads (more so in the left gonad) by E3.5 (see Figure 3) [42,192]. They express the diagnostic CVH (VASA) gene, which encodes an ATP-dependent RNA helicase [71]. While meiosis is initiated in female germ cells of the left gonadal cortex from E12.5 (based upon expression of the premeiotic marker, STRA8) [189], entry of male chicken germ cells into mitotic arrest is poorly documented. Embryonic chicken gonads express both the RA-synthesising enzyme, RALDH2, and the degrading enzyme, CYP26B1 [189], suggesting a role for RA in regulating meiosis, as in mouse. In embryonic chicken gonads cultured in vitro, exogenous RA can stimulate meiosis, an effect blunted by RALDH2 inhibition [193]. In the male chicken embryo, and unlike in mouse, Sertoli cells express both RALDH2 and CYP26B1 [189]. It seems curious that RA synthesis would occur in the seminiferous cords if the PGCs must be protected from RA in males. Hence, the co-expression of CYP26B1 to degrade the RA might be crucial. Alternatively, RA may not mediate induction of embryonic induction of meiosis in chicken, as has recently been debated in mouse [188]. Germ cell meiosis can be initiated in male chicken gonads cultured in the presence of the CYP26B1 inhibitor, ketoconazole [194], suggesting that either RA is involved in meiosis induction, or that CYP26B1 might metabolise another undefined substrate that opposes meiosis. In vitro data indicate that RA can promote PGC proliferation and that male chicken germ cells actually require RA to transition from the PGC stage into spermatogonial stem cells [191,195].

$\mathrm{CVH}$ immunostaining and flow cytometry have been used to study the dynamics of chicken embryonic germ cells $[196,197]$. Germ cell development in the embryonic chicken testis centres around cell cycle control and the meiosis versus mitosis decision. In E6 gonads, approximately 1200 PGCs are present in male and female embryonic chicken gonads. As gonadal sex differentiation proceeds, germ cells proliferate, but much more rapidly in females (24,000 in females vs 15,000 PGCs in males at $E 10$ and 88,000 vs 17,000 by hatching) [196]. In the developing testis, embryonic PGC proliferation peaks around E14 (stage 38), at which time most germ cells are at G0/G1 of the cell cycle. By hatching, over $95 \%$ of male germ cells are at the G0/G1 phase, reflecting widespread mitotic arrest. The trigger for germ cell proliferation and subsequent arrest in the embryonic testis not firmly established, but it involves signalling from Sertoli cells. Studies in the mouse embryo implicate TGF $\beta$ super family members (TGF $\beta$, Nodal, Activin A and BMPs) $[198,199]$. In the chicken embryo, germ cell proliferation and survival require FGF, and the MEK/ERK and PI3K/AKT intracellular signalling pathways (reviewed in [200]). Interestingly, our 
recent single cell RNA-seq data has revealed sexually dimorphic gene expression in chicken PGCs prior to mitotic arrest in males or meiosis entry in females [86]. This suggests that the differentiating gonad initiates specific male and female genetic programs earlier than detected by the cell cycle changes observed later in embryogenesis. In the mouse, RNA-seq has been applied to spermatogenesis, identifying novel stage-specific biomarkers and the developmental roadmap governing differentiation of the male germline [201,202]. Such approaches are yet to be applied to avian spermatogenesis.

\section{Interstitial Cells of the Embryonic Chicken Testis}

Perhaps the most poorly understood cells of the embryonic testis are the non-steroidogenic interstitial cells. That is, those outside the seminiferous cords. These cells contribute to the peritubular myoid population, that surrounds the testis cords $[203,204]$. In the chicken embryo, these cells derive at least in part from the coelomic epithelium. When the coelomic epithelium is electroporated with an integrating GFP expression plasmid construct prior gonadogenesis at E2.5 (stage 14/15), labelled cells are found throughout the interstitium - and not in the testis cords - up to seven days later [86]. The interstitial cells express high levels of extracellular matrix genes, collagens, DCN, POSTN and TCF21. In E8.5 gonads, male interstitial cells can be differentiated from their female counterparts by up-regulation of ACTA2 ( $\alpha$-Smooth Muscle Actin), suggesting this interstitial population to be also the source of peritubular myoid cells (Figure 5) [86]. The origin of these cells is the coelomic epithelium, via an epithelial to mesenchyme transition and ingression into the gonad form E2.5. In the male avian embryo, due to the absence of estrogens, the coelomic epithelial cells do not proliferate to form a cortex, as in females. After furnishing interstitial cell progenitors, the epithelial layer flattens progressively to form squamous like epithelium [16].

\section{Summary and Future Directions}

Avian testis development represents an ideal model for understanding the molecular genetics of vertebrate gonadal sex differentiation. Much of our knowledge in this area has come from studies on the chicken embryo. Figure 7 summarises testis development in the chicken and the central role of DMRT1. The early gonadal primordium forms under the inferred influence of the transcription factors SF1, WT1, GATA4, and the proven signalling molecules $\mathrm{SHH}$, BMP and FGF9. In both genetic sexes, resident mesenchymal cells adopt a molecular signature comprising the transcription factors DMRT1, OSR1, PAX2 and the signalling molecule WNT4. PAX2 expression is conserved across other avians. Also, in all birds examined, Z-linked DMRT1 expression is higher in males than in females. This higher expression (an initial two-fold dosage) is sufficient to drive specification of the pre-Sertoli cell lineage. In males, PAX2, OSR1 and WNT4 expression decline as DMRT1 expression increases. DMRT1 is required for SOX9, HEMGN and $A M H$ expression, while inhibiting the FOXL2/ Aromatase female pathway. A subset of Sertoli cells up-regulate steroidogenic markers, giving rise the fetal Leydig cells. Signals from the Sertoli cell lineage must also drive interstitial cell development, and formation of the squamous surface epithelium, and induction of germ cell mitotic arrest (Figure 7A) though the exact nature of those signals is unknown. The resulting organ is a structurally and fu

Several questions around avian testis development remain to be answered. Of particular interest is how DMRT1 is activated and how it initiates the testis developmental pathway. While the regulatory region required for DMRT1 expression in rat Sertoli cells has been described $[205,206]$, this data is lacking for chicken DMRT1. Based on expression colocalization, the GATA4 transcription factor is a likely common regulator [205]. However, in vivo and in vitro promoter and enhancer analysis needs to be conducted to empirically determine the regulatory region in chicken. The factors responsible for DMRT1 transcriptional activation in chicken must be present in both sexes, but the outcome must be different based on $\mathrm{Z}$ sex chromosome dosage. It is intriguing to speculate how a two-fold dosage difference in DMRT1 can direct testis vs ovary formation. This initial two-fold difference in 
expression must be amplified, as DMRT1 expression levels become significantly elevated in males versus females as gonadal development proceeds [12,75], pointing to positive feedback of DMRT1 on its own expression. DMRT1 ChIP- seq experiments are required to identify the direct transcriptional targets of $D M R T 1$, which are likely to be genes subjected to both positive and negative regulation. SOX9, HEMGN, and AMH are targets, as they respond to DMRT1 manipulation, though this could be indirect. The clear importance of gene dosage suggests that DMRT1 may interact with other proteins. The protein can form heterodimers with other DM domain factors in mammals [149], and may do so in chicken, or it may dimerise with other factors. The exact relationship between DMRT1, HEMGN and SOX9 also requires further analysis. What are the targets of HEMGN? Does it act together with DMRT1?

A

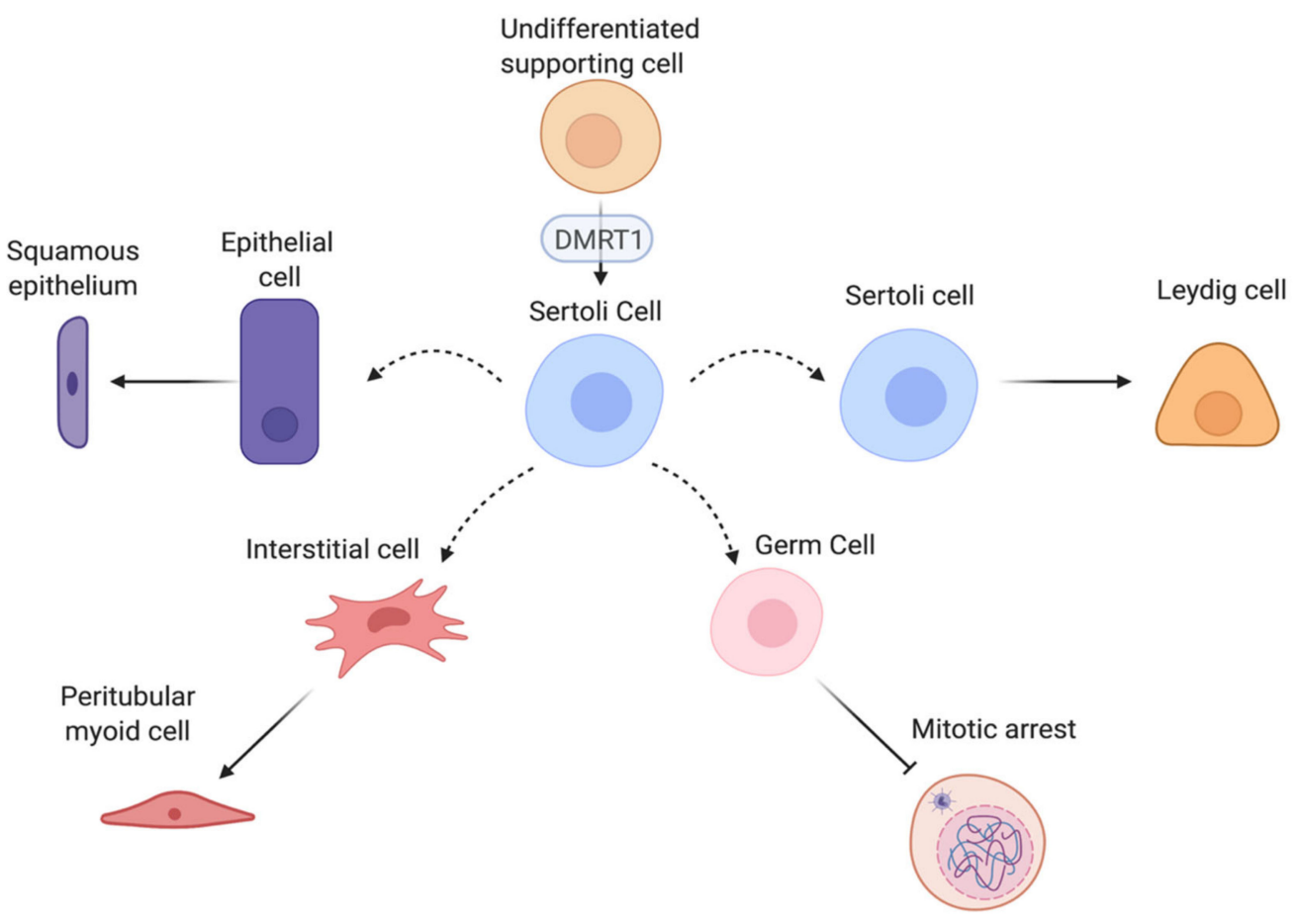

B Testis

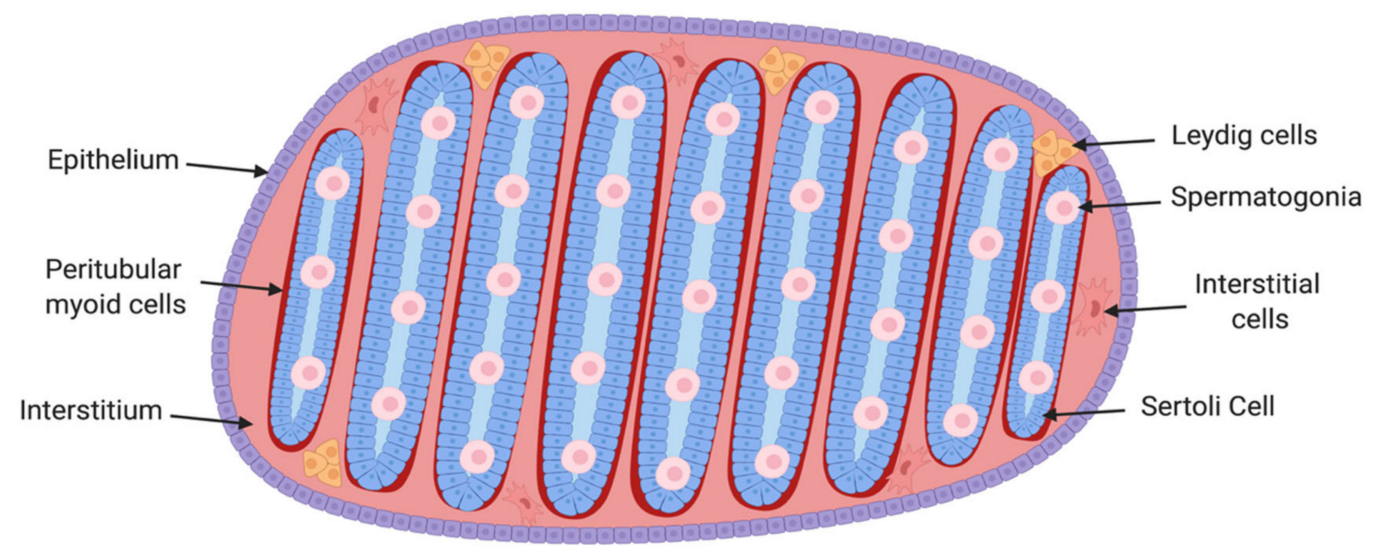

Figure 7. Testicular differentiation in the chicken embryo. (A) The first cells to differentiate are the Sertoli cells. They then regulate differentiation of other cell types in the testis. Epithelial cells become squamous, interstitial cells differentiate into peritubular myoid cells and upregulate ACTA2. Germ cells do not enter meiosis and are arrested in in G1/G0. Some Sertoli cells differentiate into steroidogenic Leydig cells. (B) The testis has a clear organised structure of seminiferous tubules, containing Sertoli cells and germ cells. Myoid cells are present surrounding those tubules. Leydig cells, and interstitial cells are located in the space between the tubules. Image created with BioRender.com. 
Another area for research is epigenetics. At present, there is very little known about the epigenetic landscape of the embryonic chicken gonad. One study reported sex-specific epigenetic marks on the chicken CYP19A1 (aromatase) gene (methylation and histone lysine methylation) and described how these marks are only partially modified when $\mathrm{ZZ}$ gonads are femininsed with estradiol [207]. This suggests that epigenetic signatures on key sex genes may be relatively stable in chicken. It will be of interest to examine the epigenetic marks on genes such as DMRT1, especially given the recent finding that temperature can induce histone modifications to the DMRT1 locus as a molecular mechanism underling temperature-dependent sex determination in some reptiles. In the red-eared slider turtle, Trachemys scripta, thermosensitive H3K27 methylase, KDM6B, directly promotes the transcription of DMRT1 by eliminating trimethylation of H3K27 near its promoter [208]. Histone and DNA methylation should be examined during gonadogenesis in avian species.

Lastly, knowledge of the interaction between Sertoli cells and germ cells will be important for poultry science and for saving endangered bird species. Most recently, methods of harvesting, storing and manipulating avian germ cells have been perfected $[43,209,210]$ and methods of producing transgenic or knockout birds have been refined [24,115,211,212]. These methods have been built on the accumulated knowledge gathered on gonadal development and germ cell specification in birds. Researchers have successfully introduced germ cells into the embryonic gonads of chicken embryos that have been modified to lack all endogenous germ cells, greatly enhancing germline transmission [44]. This approach will be very useful for potentially propagating rare species or breeds in surrogate hosts and will have application to the global poultry industry. Hence, enhancing knowledge of avian testis formation and germ cell development will shed light on gonadogenesis more broadly and will have important direct application to avian biology.

Author Contributions: Conceptualization, C.A.S., M.A.E. and A.T.M.; methodology, M.A.E.; writingoriginal draft preparation, M.A.E. and C.A.S.; writing-review and editing, C.A.S.; supervision, C.A.S.; project administration, C.A.S.; funding acquisition, C.A.S. All authors have read and agreed to the published version of the manuscript.

Funding: Please add: This research was funded by The Australian Research Council (ARC) Discovery Project grant number DP200100709.

Institutional Review Board Statement: Not applicable.

Informed Consent Statement: Not applicable.

Acknowledgments: The authors acknowledge the Monash University Histology Platform. Fixed adult chicken testes were provided by Tim Doran and Terri O'Neill, CSIRO, Geelong, Australia.

Conflicts of Interest: The authors declare no conflict of interest.

\section{References}

1. Doran, T.J.; Morris, K.R.; Wise, T.G.; O’Neil, T.E.; Cooper, C.A.; Jenkins, K.A.; Tizard, M.L.V. Sex selection in layer chickens. Anim. Prod. Sci. 2018, 58, 476. [CrossRef]

2. Krautwald-Junghanns, M.-E.; Cramer, K.; Fischer, B.; Förster, A.; Galli, R.; Kremer, F.; Mapesa, E.U.; Meissner, S.; Preisinger, R.; Preusse, G.; et al. Current approaches to avoid the culling of day-old male chicks in the layer industry, with special reference to spectroscopic methods. Poult. Sci. 2018, 97, 749-757. [CrossRef]

3. Chue, J.; Smith, C.A. Sex determination and sexual differentiation in the avian model. FEBS J. 2011, 278, 1027-1034. [CrossRef]

4. Major, A.; Ayers, K.L.; Chue, J.; Roeszler, K.N.; A Smith, C. FOXL2 antagonises the male developmental pathway in embryonic chicken gonads. J. Endocrinol. 2019, 243, 211-228. [CrossRef] [PubMed]

5. Sekido, R.; Lovell-Badge, R. Mechanisms of gonadal morphogenesis are not conserved between chick and mouse. Dev. Biol. 2007, 302, 132-142. [CrossRef]

6. Guioli, S.; Zhao, D.; Nandi, S.; Clinton, M.; Lovell-Badge, R. Oestrogen in the chick embryo can induce chromosomally male ZZ left gonad epithelial cells to form an ovarian cortex that can support oogenesis. Development 2020, 147, dev181693. [CrossRef]

7. Yoshino, T.; Murai, H.; Saito, D. Hedgehog-BMP signalling establishes dorsoventral patterning in lateral plate mesoderm to trigger gonadogenesis in chicken embryos. Nat. Commun. 2016, 7, 12561. [CrossRef] [PubMed]

8. Hirst, C.E.; Serralbo, O.; Ayers, K.L.; Roeszler, K.N.; Smith, C.A. Genetic manipulation of the avian urogenital system using in ovo electroporation. Avian Reptil. Dev. Biol. 2017, 1650, 177-190. [CrossRef] 
9. Nanda, I.; Schlegelmilch, K.; Haaf, T.; Schartl, M.; Schmid, M. Synteny conservation of the Z chromosome in 14 avian species (11 families) supports a role for $Z$ dosage in avian sex determination. Cytogenet. Genome Res. 2008, 122, 150-156. [CrossRef] [PubMed]

10. Handley, L.L.; Ceplitis, H.; Ellegren, H. Evolutionary strata on the chicken z chromosome: Implications for sex chromosome evolution. Genetics 2004, 167, 367-376. [CrossRef]

11. Fridolfsson, A.-K.; Cheng, H.; Copeland, N.G.; Jenkins, N.A.; Liu, H.-C.; Raudsepp, T.; Woodage, T.; Chowdhary, B.; Halverson, J.; Ellegren, H. Evolution of the avian sex chromosomes from an ancestral pair of autosomes. Proc. Natl. Acad. Sci. USA 1998, 95, 8147-8152. [CrossRef]

12. Ayers, K.L.; Davidson, N.M.; Demiyah, D.; Roeszler, K.N.; Grützner, F.; Sinclair, A.H.; Oshlack, A.; Smith, C.A. RNA sequencing reveals sexually dimorphic gene ex-pression before gonadal differentiation in chicken and allows comprehensive annotation of the W-chromosome. Genome Biol. 2013, 14, 1-17. [CrossRef] [PubMed]

13. Xu, L.; Zhou, Q. The female-specific W chromosomes of birds have conserved gene contents but are not feminized. Genes 2020, 11, 1126. [CrossRef]

14. Smeds, L.; Warmuth, V.; Bolivar, P.; Uebbing, S.; Burri, R.; Suh, A.; Nater, A.; Bureš, S.; Garamszegi, L.Z.; Hogner, S.; et al. Evolutionary analysis of the female-specific avian W chromosome. Nat. Commun. 2015, 6, 7330. [CrossRef] [PubMed]

15. Zhao, D.; McBride, D.; Nandi, S.; McQueen, H.A.; McGrew, M.J.; Hocking, P.M.; Lewis, P.D.; Sang, H.M.; Clinton, M. Somatic sex identity is cell autonomous in the chicken. Nature 2010, 464, 237-242. [CrossRef] [PubMed]

16. Major, A.; Smith, C.A. Sex reversal in birds. Sex. Dev. 2016, 10, 288-300. [CrossRef] [PubMed]

17. Morris, K.; Hirst, C.E.; Major, A.T.; Ezaz, T.; Ford, M.; Bibby, S.; Doran, T.J.; Smith, C.A. Gonadal and endocrine analysis of a gynandromorphic chicken. Endocrinology 2018, 159, 3492-3502. [CrossRef]

18. Clinton, M.; Zhao, D.; Nandi, S.; McBride, D. Evidence for avian cell autonomous sex identity (CASI) and implications for the sex-determination process? Chromosome Res. 2012, 20, 177-190. [CrossRef]

19. Scheib, D. Effects and role of estrogens in avian gonadal differentiation. Mech. Gonadal Differ. Vertebr. 1983, 87-92. [CrossRef]

20. Nishikimi, H.; Kansaku, N.; Saito, N.; Usami, M.; Ohno, Y.; Shimada, K. Sex differentiation and mRNA expression of P450c17, P450arom and AMH in gonads of the chicken. Mol. Reprod Dev. 2000, 55, 20-30. [CrossRef]

21. Andrews, J.E.; Smith, C.A.; Sinclair, A.H. Sites of estrogen receptor and aromatase expression in the chicken embryo. Gen. Comp. Endocr. 1997, 108, 182-190. [CrossRef]

22. Elbrecht, A.; Smith, R. Aromatase enzyme activity and sex determination in chickens. Science 1992, 255, 467-470. [CrossRef] [PubMed]

23. Lambeth, L.S.; Cummins, D.M.; Doran, T.J.; Sinclair, A.H.; Smith, C.A. Overexpression of aromatase alone is sufficient for ovarian development in genetically male chicken embryos. PLoS ONE 2013, 8, e68362. [CrossRef]

24. Ioannidis, J.; Taylor, G.; Zhao, D.; Liu, L.; Idoko-Akoh, A.; Gong, D.; Lovell-Badge, R.; Guioli, S.; McGrew, M.J.; Clinton, M. Primary sex determination in birds depends on DMRT1 dosage, but gonadal sex does not determine adult secondary sex characteristics. Proc. Natl. Acad. Sci. USA 2021, 118. [CrossRef] [PubMed]

25. Zhang, S.O.; Mathur, S.; Hattem, G.; Tassy, O.; Pourquié, O. Sex-dimorphic gene expression and ineffective dosage compensation of Z-linked genes in gastrulating chicken embryos. BMC Genom. 2010, 11, 13. [CrossRef]

26. Graves, J.A.M. Avian sex, sex chromosomes, and dosage compensation in the age of genomics. Chromosom. Res. 2014, 22, 45-57. [CrossRef] [PubMed]

27. Uebbing, S.; Künstner, A.; Mäkinen, H.; Ellegren, H. Transcriptome sequencing reveals the character of incomplete dosage compensation across multiple tissues in flycatchers. Genome Biol. Evol. 2013, 5, 1555-1566. [CrossRef]

28. Adolfsson, S.; Ellegren, H. Lack of dosage compensation accompanies the arrested stage of sex chromosome evolution in ostriches. Mol. Biol. Evol. 2013, 30, 806-810. [CrossRef] [PubMed]

29. Birchler, J.A. Dosage compensation for the birds. Heredity 2009, 102, 423-424. [CrossRef]

30. Melamed, E.; Arnold, A.P. Regional differences in dosage compensation on the chicken Z chromosome. Genome Biol. 2007, 8, 1-10. [CrossRef] [PubMed]

31. Itoh, Y.; Melamed, E.; Yang, X.; Kampf, K.; Wang, S.; Yehya, N.; Van Nas, A.; Replogle, K.; Band, M.R.; Clayton, D.F.; et al. Dosage compensation is less effective in birds than in mammals. J. Biol. 2007, 6, 1-15. [CrossRef] [PubMed]

32. Ellegren, H.; Hultin-Rosenberg, L.; Brunström, B.; Dencker, L.; Kultima, K.; Scholz, B. Faced with inequality: Chicken do not have a general dosage compensation of sex-linked genes. BMC Biol. 2007, 5, 1-12. [CrossRef] [PubMed]

33. Smith, C.A.; Major, A.T.; Estermann, M.A. The curious case of avian sex determination. Trends Genet. 2021, 37, 496-497. [CrossRef] [PubMed]

34. Leska, A.; Dusza, L. Seasonal changes in the hypothalamo-pituitary-gonadal axis in birds. Reprod. Biol. $2007,7$.

35. Kirby, J.F.D. Reproduction in Male Birds. Sturkie's Avian Physiology, 5th ed; Academic Press: Main St. Salt Lake City, UT, USA, 1999; pp. 597-615.

36. McCartney, M.G. Sexual maturity in broiler breeder males. Poult. Sci. 1978, 57, 1720-1722. [CrossRef]

37. Cooksey, E.J.; Rothwell, B. The ultrastructure of the Sertoli cell and its differentiation in the domestic fowl (Gallus domesticus). J. Anat. 1973, 114, 329-345. [PubMed]

38. Ishii, S.; Furuya, T. Effects of purified chicken gonadotropins on the chick testis. Gen. Comp. Endocrinol. 1975, 25, 1-8. [CrossRef] 
39. Brown, N.; Follett, B. Effects of androgens on the testes of intact and hypophysectomized Japanese quail. Gen. Comp. Endocrinol. 1977, 33, 267-277. [CrossRef]

40. Cooper, C.A.; Challagulla, A.; Jenkins, K.A.; Wise, T.G.; O'Neil, T.; Morris, K.; Tizard, M.; Doran, T.J. Generation of gene edited birds in one generation using sperm transfection assisted gene editing (STAGE). Transgenic Res. 2016, 26, 331-347. [CrossRef] [PubMed]

41. Guibert, E.; Brière, S.; Pelletier, R.; Brillard, J.P.; Froment, P. Characterization of chicken Sertoli cells in vitro. Poult. Sci. 2011, 90, 1276-1286. [CrossRef]

42. Nakamura, Y.; Kagami, H.; Tagami, T. Development, differentiation and manipulation of chicken germ cells. Dev. Growth Differ. 2013, 55, 20-40. [CrossRef]

43. Ballantyne, M.; Woodcock, M.; Doddamani, D.; Hu, T.; Taylor, L.; Hawken, R.J.; McGrew, M.J. Direct allele introgression into pure chicken breeds using Sire Dam Surrogate (SDS) mating. Nat. Commun. 2021, 12, 1-10. [CrossRef] [PubMed]

44. Woodcock, M.E.; Gheyas, A.A.; Mason, A.; Nandi, S.; Taylor, L.; Sherman, A.; Smith, J.; Burt, D.W.; Hawken, R.; McGrew, M.J. Reviving rare chicken breeds using genetically engineered sterility in surrogate host birds. Proc. Natl. Acad. Sci. USA 2019, 116, 20930-20937. [CrossRef] [PubMed]

45. Mucksova, J.; Reinisova, M.; Kalina, J.; Lejckova, B.; Hejnar, J.; Trefil, P. Conservation of chicken male germline by orthotopic trans-plantation of primordial germ cells from genetically distant donorsdagger. Biol. Reprod. 2019, 101, 200-207. [CrossRef] [PubMed]

46. Park, T.S.; Jeong, D.K.; Kim, J.N.; Song, G.H.; Hong, Y.H.; Lim, J.M.; Han, J.Y. Improved germline transmission in chicken chimeras produced by trans-plantation of gonadal primordial germ cells into recipient embryos. Biol. Reprod. 2003, 68, 1657-1662. [CrossRef] [PubMed]

47. Lambeth, L.S.; Ayers, K.L.; Cutting, A.; Doran, T.J.; Sinclair, A.; Smith, C. Anti-müllerian hormone is required for chicken embryonic urogenital system growth but not sexual differentiation. Biol. Reprod. 2015, 93, 138. [CrossRef]

48. Smith, C.A.; Major, A.T.; Estermann, M.A. Chickens, sex, and revisiting an old paradigm. Endocrinology 2021, 162, bqab106. [CrossRef]

49. Mi, Y.; He, B.; Li, J.; Zhang, C. Progesterone regulates chicken embryonic germ cell meiotic initiation independent of retinoic acid signaling. Theriogenology 2014, 82, 195-203. [CrossRef]

50. Guioli, S.; Nandi, S.; Zhao, D.; Burgess-Shannon, J.; Lovell-Badge, R.; Clinton, M. Gonadal Asymmetry and Sex Determination in Birds. Sex. Dev. 2014, 8, 227-242. [CrossRef]

51. Carlon, N.; Stahl, A. Origin of the somatic components in chick embryonic gonads. Arch. D'anatomie Microsc. Morphol. Exp. 1985, $74,52-59$.

52. Hamburger, V.; Hamilton, H.L. A series of normal stages in the development of the chick embryo. J. Morphol. 1951, 88, 49-92. [CrossRef] [PubMed]

53. Yoshino, T.; Saito, D. Epithelial-to-mesenchymal transition-based morphogenesis of dorsal mesentery and gonad. Semin. Cell Dev. Biol. 2018, 92, 105-112. [CrossRef] [PubMed]

54. Ebensperger, C.; Drews, U.; Mayerová, A.; Wolf, U. Serological HY antigen in the female chicken occurs during gonadal differentiation. Differentiation 1988, 37, 186-191. [CrossRef]

55. Yoshioka, H.; Ishimaru, Y.; Sugiyama, N.; Tsunekawa, N.; Noce, T.; Kasahara, M.; Morohashi, K.I. Mesonephric FGF signaling is associated with the de-velopment of sexually indifferent gonadal primordium in chick embryos. Dev. Biol. 2005, 280, 150-161. [CrossRef]

56. Oréal, E.; Mazaud, S.; Picard, J.Y.; Magre, S.; Carré-Eusèbe, D. Different patterns of anti-Mullerian hormone expression, as related to DMRT1, SF-1, WT1, GATA-4, Wnt-4, and Lhx9 expression, in the chick differentiating gonads. Dev. Dynam. 2002, 225, 221-232. [CrossRef]

57. Colvin, J.S.; Green, R.P.; Schmahl, J.; Capel, B.; Ornitz, D. Male-to-female sex reversal in mice lacking fibroblast growth factor. Cell 2001, 104, 875-889. [CrossRef]

58. Kim, Y.; Kobayashi, A.; Sekido, R.; DiNapoli, L.; Brennan, J.; Chaboissier, M.-C.; Poulat, F.; Behringer, R.R.; Lovell-Badge, R.; Capel, B. FGF9 and Wnt4 Act as antagonistic signals to regulate mammalian sex determination. PLoS Biol. 2006, 4, e187. [CrossRef]

59. Luo, X.; Ikeda, Y.; Parker, K.L. A cell-specific nuclear receptor is essential for adrenal and gonadal development and sexual differentiation. Cell 1994, 77, 481-490. [CrossRef]

60. Ayers, K.L.; Smith, C.; Lambeth, L.S. The molecular genetics of avian sex determination and its manipulation. Genesis 2013, 51, 325-336. [CrossRef] [PubMed]

61. Hirst, C.; Major, A.; Ayers, K.L.; Brown, R.J.; Mariette, M.; Sackton, T.; Smith, C. Sex reversal and comparative data undermine the W chromosome and support Z-linked DMRT1 as the regulator of gonadal sex differentiation in birds. Endocrinology 2017, 158, 2970-2987. [CrossRef]

62. Smith, C.A.; Roeszler, K.N.; Sinclair, A.H. Genetic evidence against a role for W-linked histidine triad nucleotide binding protein (HINTW) in avian sex determination. Int. J. Dev. Biol. 2009, 53, 59-67. [CrossRef] [PubMed]

63. Bellott, D.W.; Page, D.C. Dosage-sensitive functions in embryonic development drove the survival of genes on sex-specific chromosomes in snakes, birds, and mammals. Genome Res. 2021, 31, 198-210. [CrossRef] [PubMed] 
64. Bellott, D.W.; Skaletsky, H.; Cho, T.-J.; Brown, L.; Locke, D.; Chen, N.; Galkina, S.; Pyntikova, T.; Koutseva, N.; Graves, T.; et al. Avian W and mammalian Y chromosomes convergently retained dosage-sensitive regulators. Nat. Genet. 2017, 49, 387-394. [CrossRef] [PubMed]

65. Bellott, D.W.; Skaletsky, H.; Pyntikova, T.; Mardis, E.R.; Graves, T.; Kremitzki, C.; Brown, L.G.; Rozen, S.G.; Warren, W.C.; Wilson, R.K.; et al. Convergent evolution of chicken $\mathrm{Z}$ and human $\mathrm{X}$ chromosomes by expansion and gene acquisition. Nature 2010, 466, 612-616. [CrossRef]

66. Ezaz, T.; Stiglec, R.; Veyrunes, F.; Graves, J. Relationships between vertebrate ZW and XY sex chromosome systems. Curr. Biol. 2006, 16, R736-R743. [CrossRef]

67. Smith, C.A.; Roeszler, K.N.; Ohnesorg, T.; Cummins, D.M.; Farlie, P.G.; Doran, T.; Sinclair, A. The avian Z-linked gene DMRT1 is required for male sex determination in the chicken. Nature 2009, 461, 267-271. [CrossRef]

68. Nakata, T.; Ishiguro, M.; Aduma, N.; Izumi, H.; Kuroiwa, A. Chicken hemogen homolog is involved in the chicken-specific sex-determining mechanism. Proc. Natl. Acad. Sci. USA 2013, 110, 3417-3422. [CrossRef]

69. Stahl, A.; Carlon, N. Morphogenesis of the sex cords and the significance of the medullary zone of the gonad in the chick embryo. Acta Anatom 1973, 85, 248-274. [CrossRef]

70. Van Limborgh, J. The first sign of sexual differentiation of the gonads in chick embryos. Arch. D'anatomie Microsc. Morphol. Exp. 1968, 57, 79-90.

71. Tsunekawa, N.; Naito, M.; Sakai, Y.; Nishida, T.; Noce, T. Isolation of chicken vasa homolog gene and tracing the origin of primordial germ cells. Development 2000, 127, 2741-2750. [CrossRef]

72. Smith, C.A.; Sinclair, A. Sex determination: Insights from the chicken. BioEssays 2004, 26, 120-132. [CrossRef]

73. Zaccanti, F.; Vallisneri, M.; Quaglia, A. Early aspects of sex differentiation in the gonads of chick embryos. Differentiation 1990, 43, 71-80. [CrossRef] [PubMed]

74. Nagano, R.; Kanai, Y.; Kurohmaru, M.; Hayashi, Y.; Nishida, T. Distribution of desmin and fibronectin in chick embryo gonad during testicular cord formation. J. Veter-Med. Sci. 1997, 59, 581-585. [CrossRef]

75. Lambeth, L.S.; Raymond, C.; Roeszler, K.N.; Kuroiwa, A.; Nakata, T.; Zarkower, D.; Smith, C.A. Over-expression of DMRT1 induces the male pathway in embryonic chicken gonads. Dev. Biol. 2014, 389, 160-172. [CrossRef]

76. DeFalco, T.; Takahashi, S.; Capel, B. Two distinct origins for Leydig cell progenitors in the fetal testis. Dev. Biol. 2011, 352, 14-26. [CrossRef]

77. Combes, A.; Wilhelm, D.; Davidson, T.; Dejana, E.; Harley, V.; Sinclair, A.; Koopman, P. Endothelial cell migration directs testis cord formation. Dev. Biol. 2009, 326, 112-120. [CrossRef]

78. Rotgers, E.; Jørgensen, A.; Yao, H.H.-C. At the crossroads of fate-Somatic cell lineage specification in the fetal gonad. Endocr. Rev. 2018, 39, 739-759. [CrossRef] [PubMed]

79. Karl, J.; Capel, B. Sertoli cells of the mouse testis originate from the coelomic epithelium. Dev. Biol. 1998, 203, 323-333. [CrossRef] [PubMed]

80. Stévant, I.; Kühne, F.; Greenfield, A.; Chaboissier, M.C.; Dermitzakis, E.T.; Nef, S. Dissecting cell lineage specification and sex fate determination in gonadal somatic cells using single-cell transcriptomics. Cell Rep. 2019, 26, 3272-3283. [CrossRef]

81. Stévant, I.; Neirijnck, Y.; Borel, C.; Escoffier, J.; Smith, L.B.; Antonarakis, S.E.; Dermitzakis, E.T.; Nef, S. Deciphering cell lineage specification during male sex determination with single-cell RNA sequencing. Cell Rep. 2018, 22, 1589-1599. [CrossRef]

82. Merchant-Larios, H.; Popova, L.; Reyss-Brion, M. Early morphogenesis of chick gonad in the absence of mesonephros. (morphogenesis/gonad/mesonephric agenesis). Dev. Growth Differ. 1984, 26, 403-417. [CrossRef]

83. Rodemer, E.S.; Ihmer, A.; Wartenberg, H. Gonadal development of the chick embryo following microsurgically caused agenesis of the mesonephros and using interspecific quail-chick chimaeras. J. Embryol. Exp. Morphol. 1986, 98, $269-285$.

84. Hirst, C.E.; Major, A.T.; Smith, C.A. Sex determination and gonadal sex differentiation in the chicken model. Int. J. Dev. Biol. 2018, 62, 153-166. [CrossRef] [PubMed]

85. Smith, C.A.; Roeszler, K.N.; Hudson, Q.J.; Sinclair, A.H. Avian sex determination: What, when and where? Cytogenet. Genome Res. 2007, 117, 165-173. [CrossRef]

86. Estermann, M.A.; Williams, S.; Hirst, C.E.; Roly, Z.Y.; Serralbo, O.; Adhikari, D.; Powell, D.; Major, A.; Smith, C.A. Insights into gonadal sex differentiation provided by single-cell transcriptomics in the chicken embryo. Cell Rep. 2020, 31, 107491. [CrossRef] [PubMed]

87. Tena, J.J.; Neto, A.; de la Calle-Mustienes, E.; Pereira, C.A.B.S.; Casares, F.; Gómez-Skarmeta, J.L. Odd-skipped genes encode repressors that control kidney development. Dev. Biol. 2007, 301, 518-531. [CrossRef] [PubMed]

88. Wang, Q.; Lan, Y.; Cho, E.S.; Maltby, K.M.; Jiang, R. Odd-skipped related 1 (Odd 1) is an essential regulator of heart and uro-genital development. Dev. Biol. 2005, 288, 582-594. [CrossRef] [PubMed]

89. James, R.; Kamei, C.N.; Wang, Q.; Jiang, R.; Schultheiss, T.M. Odd-skipped related 1 is required for development of the metanephric kidney and regulates formation and differentiation of kidney precursor cells. Development 2006, 133, $2995-3004$. [CrossRef] [PubMed]

90. Smith, C.A.; Shoemaker, C.M.; Roeszler, K.N.; Queen, J.; Crews, D.; Sinclair, A.H. Cloning and expression of R-Spondin1in different vertebrates suggests a conserved role in ovarian development. BMC Dev. Biol. 2008, 8, 1-16. [CrossRef]

91. Matson, C.K.; Zarkower, D. Sex and the singular DM domain: Insights into sexual regulation, evolution and plasticity. Nat. Rev. Genet. 2012, 13, 163-174. [CrossRef] 
92. Zarkower, D. DMRT genes in vertebrate gametogenesis. Curr. Top. Dev. Biol. 2013, 102, 327-356. [CrossRef] [PubMed]

93. Raymond, C.S.; Murphy, M.W.; O'Sullivan, M.G.; Bardwell, V.J.; Zarkower, D. DMRT1, a gene related to worm and fly sexual regu-lators, is required for mammalian testis differentiation. Genes Dev. 2000, 14, 2587-2595. [CrossRef]

94. Koopman, P. Sex determination: The power of DMRT1. Trends Genet. 2009, 25, 479-481. [CrossRef]

95. Kim, S.; Bardwell, V.J.; Zarkower, D. Cell type-autonomous and non-autonomous requirements for DMRT1 in postnatal testis differentiation. Dev. Biol. 2007, 307, 314-327. [CrossRef] [PubMed]

96. Matson, C.K.; Murphy, M.W.; Sarver, A.L.; Griswold, M.D.; Bardwell, V.J.; Zarkower, D. DMRT1 prevents female reprogramming in the postnatal mammalian testis. Nature 2011, 476, 101-104. [CrossRef]

97. Ye, L.; Chen, H.; Huang, S. Sex determination and maintenance: The role of DMRT1 and FOXL2. Asian J. Androl. 2017, 19, 619-624. [CrossRef]

98. Zhang, T.; Oatley, J.; Bardwell, V.J.; Zarkower, D. DMRT1 Is Required for mouse spermatogonial stem cell maintenance and replenishment. PLoS Genet. 2016, 12, e1006293. [CrossRef]

99. Lindeman, R.E.; Gearhart, M.; Minkina, A.; Krentz, A.D.; Bardwell, V.J.; Zarkower, D. Sexual cell-fate reprogramming in the ovary by DMRT1. Curr. Biol. 2015, 25, 764-771. [CrossRef] [PubMed]

100. Sun, W.; Cai, H.; Zhang, G.; Zhang, H.; Bao, H.; Wang, L.; Ye, J.; Qian, G.; Ge, C. DMRT1 is required for primary male sexual differentiation in Chinese soft-shelled turtle Pelodiscus sinensis. Sci. Rep. 2017, 7, 4433. [CrossRef]

101. Ge, C.; Ye, J.; Zhang, H.; Zhang, Y.; Sun, W.; Sang, Y.; Capel, B.; Qian, G. DMRT1 induces the male pathway in a turtle species with temperature-dependent sex determination. Development 2017, 144, 2222-2233. [PubMed]

102. Shoemaker, C.; Ramsey, M.; Queen, J.; Crews, D. Expression of SOX9, Mis, and DMRT1 in the gonad of a species with temperaturedependent sex determination. Dev. Dynam. 2007, 236, 1055-1063. [CrossRef] [PubMed]

103. Cui, Z.; Liu, Y.; Wang, W.; Wang, Q.; Zhang, N.; Lin, F.; Wang, N.; Shao, C.; Dong, Z.; Li, Y.; et al. Genome editing reveals DMRT1 as an essential male sex-determining gene in Chinese tongue sole (Cynoglossus semilaevis). Sci. Rep. 2017, 7, 42213. [CrossRef] [PubMed]

104. Masuyama, H.; Yamada, M.; Kamei, Y.; Fujiwara-Ishikawa, T.; Todo, T.; Nagahama, Y.; Matsuda, M. DMRT1 mutation causes a male-to-female sex reversal after the sex determination by Dmy in the medaka. Chromosom. Res. 2011, 20, 163-176. [CrossRef]

105. Kobayashi, T.; Matsuda, M.; Kajiura-Kobayashi, H.; Suzuki, A.; Saito, N.; Nakamoto, M.; Shibata, N.; Nagahama, Y. Two DM domain genes, DMY and DMRT1, involved in testicular differentiation and development in the medaka, Oryzias latipes. Dev. Dyn. 2004, 231, 518-526. [CrossRef]

106. Matsuda, M.; Nagahama, Y.; Shinomiya, A.; Sato, T.; Matsuda, C.; Kobayashi, T.; Morrey, C.E.; Shibata, N.; Asakawa, S.; Shimizu, N.; et al. DMY is a Y-specific DM-domain gene required for male devel-opment in the medaka fish. Nature 2002, 417, 559-563. [CrossRef] [PubMed]

107. Mawaribuchi, S.; Musashijima, M.; Wada, M.; Izutsu, Y.; Kurakata, E.; Park, M.K.; Takamatsu, N.; Ito, M. Molecular Evolution of Two Distinct DMRT1 Promoters for Germ and Somatic Cells in Vertebrate Gonads. Mol. Biol. Evol. 2016, 34, 724-733. [CrossRef] [PubMed]

108. Webster, K.; Schach, U.; Ordaz, A.; Steinfeld, J.S.; Draper, B.W.; Siegfried, K.R. DMRT1 is necessary for male sexual development in zebrafish. Dev. Biol. 2016, 422, 33-46. [CrossRef]

109. Nanda, I.; Zend-Ajusch, E.; Shan, Z.; Grützner, F.; Schartl, M.; Burt, D.; Koehler, M.; Fowler, V.; Goodwin, G.; Schneider, W.; et al. Conserved synteny between the chicken $\mathrm{Z}$ sex chromosome and human chromosome 9 includes the male regulatory gene DMRT1: A comparative (re)view on avian sex determination. Cytogenet. Genome Res. 2000, 89, 67-78. [CrossRef] [PubMed]

110. Shetty, S.; Kirby, P.; Zarkower, D.; Graves, J.A. DMRT1 in a ratite bird: Evidence for a role in sex determination and discovery of a putative regulatory element. Cytogenet. Genome Res. 2002, 99, 245-251. [CrossRef] [PubMed]

111. Zhou, Q.; Zhang, J.; Bachtrog, D.; An, N.; Huang, Q.; Jarvis, E.D.; Gilbert, M.; Zhang, G. Complex evolutionary trajectories of sex chromosomes across bird taxa. Science 2014, 346, 1246338. [CrossRef]

112. Shan, Z.; Nanda, I.; Wang, Y.; Schmid, M.; Vortkamp, A.; Haaf, T. Sex-specific expression of an evolutionarily conserved male regulatory gene, DMRT1, in birds. Cytogenet. Cell Genet. 2000, 89, 252-257. [CrossRef] [PubMed]

113. Raymond, C.S.; Kettlewell, J.R.; Hirsch, B.; Bardwell, V.J.; Zarkower, D. Expression of DMRT1 in the genital ridge of mouse and chicken embryos suggests a role in vertebrate sexual development. Dev. Biol. 1999, 215, 208-220. [CrossRef] [PubMed]

114. Smith, C.; McClive, P.J.; Western, P.; Reed, K.J.; Sinclair, A. Conservation of a sex-determining gene. Nature 1999, 402, 601-602. [CrossRef] [PubMed]

115. Lee, H.J.; Seo, M.; Choi, H.J.; Rengaraj, D.; Jung, K.M.; Park, J.S.; Lee, K.Y.; Kim, Y.M.; Park, K.J.; Han, S.T.; et al. DMRT1 gene disruption alone induces incomplete gonad feminization in chicken. FASEB J. 2021, 35, e21876. [CrossRef]

116. Bai, D.-P.; Chen, Y.; Hu, Y.-Q.; He, W.-F.; Shi, Y.-Z.; Fan, Q.-M.; Luo, R.-T.; Li, A. Transcriptome analysis of genes related to gonad differentiation and development in Muscovy ducks. BMC Genom. 2020, 21, 1-17. [CrossRef] [PubMed]

117. Naurin, S.; Hasselquist, D.; Bensch, S.; Hansson, B. Sex-biased gene expression on the avian Z chromosome: Highly ex-pressed genes show higher male-biased expression. PLoS ONE 2012, 7, e46854. [CrossRef]

118. Wright, A.E.; Moghadam, H.; Mank, J. Trade-off between selection for dosage compensation and masculinization on the avian $\mathrm{Z}$ chromosome. Genetics 2012, 192, 1433-1445. [CrossRef] [PubMed] 
119. Omotehara, T.; Smith, C.; Mantani, Y.; Kobayashi, Y.; Tatsumi, A.; Nagahara, D.; Hashimoto, R.; Hirano, T.; Umemura, Y.; Yokoyama, T.; et al. Spatiotemporal expression patterns of doublesex and mab-3 related transcription factor 1 in the chicken developing gonads and Müllerian ducts. Poult. Sci. 2014, 93, 953-958. [CrossRef]

120. Lei, N.; Hornbaker, K.I.; Rice, D.A.; Karpova, T.; Agbor, V.A.; Heckert, L.L. Sex-specific differences in mouse DMRT1 expression are both cell type- and stage-dependent during gonad development. Biol. Reprod. 2007, 77, 466-475. [CrossRef]

121. Krentz, A.D.; Murphy, M.W.; Sarver, A.L.; Griswold, M.D.; Bardwell, V.J.; Zarkower, D. DMRT1 promotes oogenesis by transcriptional activation of Stra8 in the mammalian fetal ovary. Dev. Biol. 2011, 356, 63-70. [CrossRef] [PubMed]

122. Tanaka, T.; Kanatsu-Shinohara, M.; Hirose, M.; Ogura, A.; Shinohara, T. Pluripotent cell derivation from male germline cells by suppression of DMRT1 and Trp53. J. Reprod. Dev. 2015, 61, 473-484. [CrossRef] [PubMed]

123. Krentz, A.D.; Murphy, M.W.; Kim, S.; Cook, M.S.; Capel, B.; Zhu, R.; Matin, A.; Sarver, A.L.; Parker, K.L.; Griswold, M.D.; et al. The DM domain protein DMRT1 is a dose-sensitive regulator of fetal germ cell proliferation and pluripotency. Proc. Natl. Acad. Sci. USA 2009, 106, 22323-22328. [CrossRef] [PubMed]

124. Matson, C.K.; Murphy, M.W.; Griswold, M.D.; Yoshida, S.; Bardwell, V.J.; Zarkower, D. The mammalian doublesex homolog DMRT1 is a tran-scriptional gatekeeper that controls the mitosis versus meiosis decision in male germ cells. Dev. Cell 2010, 19, 612-624. [CrossRef] [PubMed]

125. Morrish, B.C.; Sinclair, A.H. Vertebrate sex determination: Many means to an end. Reproduction 2002, 124, 447-457. [CrossRef]

126. Sekido, R.; Bar, I.; Narváez, V.; Penny, G.; Lovell-Badge, R. SOX9 is up-regulated by the transient expression of SRY specifically in Sertoli cell precursors. Dev. Biol. 2004, 274, 271-279. [CrossRef] [PubMed]

127. Sekido, R.; Lovell-Badge, R. Sex determination involves synergistic action of SRY and SF1 on a specific SOX9 enhancer. Nature 2008, 453, 930-934. [CrossRef] [PubMed]

128. Gonen, N.; Lovell-Badge, R. The regulation of SOX9 expression in the gonad. Curr. Top. Dev. Biol. 2019, 134, 223-252. [CrossRef] [PubMed]

129. Croft, B.; Ohnesorg, T.; Hewitt, J.; Bowles, J.; Quinn, A.; Tan, J.; Corbin, V.; Pelosi, E.; Bergen, J.V.D.; Sreenivasan, R.; et al. Human sex reversal is caused by duplication or deletion of core enhancers upstream of SOX9. Nat. Commun. 2018, 9, 1-10. [CrossRef]

130. Gonen, N.; Quinn, A.; O’Neill, H.C.; Koopman, P.; Lovell-Badge, R. Normal levels of SOX9 expression in the developing mouse testis depend on the TES/TESCO enhancer, but this does not act alone. PLoS Genet. 2017, 13, e1006520.

131. Takada, S.; Ota, J.; Kansaku, N.; Yamashita, H.; Izumi, T.; Ishikawa, M.; Wada, T.; Kaneda, R.; Choi, Y.L.; Koinuma, K.; et al. Nucleotide sequence and embryonic expression of quail and duck SOX9 genes. Gen. Comp. Endocrinol. 2006, 145, 208-213. [CrossRef]

132. Kent, J.; Wheatley, S.C.; Andrews, J.E.; Sinclair, A.; Koopman, P. A male-specific role for SOX9 in vertebrate sex determination. Development 1996, 122, 2813-2822. [CrossRef]

133. Da Silva, S.M.; Hacker, A.; Harley, V.; Goodfellow, P.; Swain, A.; Lovell-Badge, R. SOX9 expression during gonadal development implies a conserved role for the gene in testis differentiation in mammals and birds. Nat. Genet. 1996, 14, 62-68. [CrossRef] [PubMed]

134. Vidal, V.P.; Chaboissier, M.-C.; de Rooij, D.; Schedl, A. SOX9 induces testis development in XX transgenic mice. Nat. Genet. 2001, 28, 216-217. [CrossRef] [PubMed]

135. De Santa Barbara, P.; Bonneaud, N.; Boizet, B.; Desclozeaux, M.; Moniot, B.; Sudbeck, P.; Scherer, G.; Poulat, F.; Berta, P. Direct interaction of SRY-related protein SOX9 and steroidogenic factor 1 regulates transcription of the human anti-Mullerian hormone gene. Mol. Cell Biol. 1998, 18, 6653-6665. [CrossRef] [PubMed]

136. Oreal, E.; Pieau, C.; Mattei, M.-G.; Josso, N.; Picard, J.-Y.; Carré-Eusèbe, D.; Magre, S. Early expression of $A M H$ in chicken embryonic gonads precedes testicularSOX9 expression. Dev. Dyn. 1998, 212, 522-532. [CrossRef]

137. Smith, C.; Smith, M.J.; Sinclair, A. Gene expression during gonadogenesis in the chicken embryo. Gene 1999, $234,395-402$. [CrossRef]

138. Wilhelm, D.; Hiramatsu, R.; Mizusaki, H.; Widjaja, L.; Combes, A.; Kanai, Y.; Koopman, P. SOX9 Regulates prostaglandin D synthase gene transcription in vivo to ensure testis development. J. Biol. Chem. 2007, 282, 10553-10560. [CrossRef]

139. Wilhelm, D.; Martinson, F.; Bradford, S.; Wilson, M.J.; Combes, A.N.; Beverdam, A.; Bowles, J.; Mizusaki, H.; Koopman, P. Sertoli cell differentiation is induced both cell-autonomously and through prostaglandin signaling during mammalian sex determination. Dev. Biol. 2005, 287, 111-124. [CrossRef]

140. Moniot, B.; Declosmenil, F.; Barrionuevo, F.; Scherer, G.; Aritake, K.; Malki, S.; Marzi, L.; Cohen-Solal, A.; Georg, I.; Klattig, J.; et al. The PGD2 pathway, independently of FGF9, amplifies SOX9 activity in Sertoli cells during male sexual differentiation. Development 2009, 136, 1813-1821. [CrossRef]

141. Moniot, B.; Boizet-Bonhoure, B.; Poulat, F. Male specific expression of lipocalin-type prostaglandin D synthase (cPTGDS) during chicken gonadal differentiation: Relationship with cSOX9. Sex. Dev. 2008, 2, 96-103. [CrossRef] [PubMed]

142. Willerton, L.; Smith, R.A.; Russell, D.; Mackay, S. Effects of FGF9 on embryonic Sertoli cell proliferation and testicular cord formation in the mouse. Int. J. Dev. Biol. 2004, 48, 637-643. [CrossRef] [PubMed]

143. Bagheri-Fam, S.; Sim, H.; Bernard, P.; Jayakody, I.; Taketo, M.M.; Scherer, G.; Harley, V. Loss of Fgfr2 leads to partial XY sex reversal. Dev. Biol. 2008, 314, 71-83. [CrossRef]

144. Kim, Y.; Bingham, N.; Sekido, R.; Parker, K.L.; Lovell-Badge, R.; Capel, B. Fibroblast growth factor receptor 2 regulates proliferation and Sertoli differentiation during male sex determination. Proc. Natl. Acad. Sci. USA 2007, 104, 16558-16563. [CrossRef] [PubMed] 
145. Schmahl, J.; Kim, Y.; Colvin, J.S.; Ornitz, D.M.; Capel, B. FGF9induces proliferation and nuclear localization of FGFR2 in Sertoli precursors during male sex determination. Development 2004, 131, 3627-3636. [CrossRef]

146. Yamashita, S.; Kataoka, K.; Yamamoto, H.; Kato, T.; Hara, S.; Yamaguchi, K.; Renard-Guillet, C.; Katou, Y.; Shirahige, K.; Ochi, H.; et al. Comparative analysis demonstrates cell type-specific conservation of SOX9 targets between mouse and chicken. Sci. Rep. 2019, 9, 1-15. [CrossRef]

147. Rahmoun, M.; Lavery, R.; Laurent-Chaballier, S.; Bellora, N.; Philip, G.K.; Rossitto, M.; Symon, A.; Pailhoux, E.; Cammas, F.; Chung, J.; et al. In mammalian foetal testes, SOX9 regulates expression of its target genes by binding to genomic regions with conserved signatures. Nucleic Acids Res. 2017, 45, 7191-7211. [CrossRef]

148. Murphy, M.W.; Sarver, A.L.; Rice, D.; Hatzi, K.; Ye, K.; Melnick, A.; Heckert, L.L.; Zarkower, D.; Bardwell, V.J. Genome-wide analysis of DNA binding and transcriptional regulation by the mammalian Doublesex homolog DMRT1 in the juvenile testis. Proc. Natl. Acad. Sci. USA 2010, 107, 13360-13365. [CrossRef] [PubMed]

149. Murphy, M.W.; Zarkower, D.; Bardwell, V.J. Vertebrate DM domain proteins bind similar DNA sequences and can heterodimerize on DNA. BMC Mol. Biol. 2007, 8, 58. [CrossRef]

150. Yang, L.; Nicholson, R.H.; Kaplan, J.; Galy, A.; Li, L. Hemogen is a novel nuclear factor specifically expressed in mouse hematopoietic development and its human homologue EDAG maps to chromosome 9q22, a region containing breakpoints of hematological neoplasms. Mech. Dev. 2001, 104, 105-111. [CrossRef]

151. Zhang, H.; Menzies, K.J.; Auwerx, J. The role of mitochondria in stem cell fate and aging. Development 2018, 145, dev143420. [CrossRef] [PubMed]

152. Wilhelm, D.; Palmer, S.; Koopman, P. Sex Determination and gonadal development in mammals. Physiol. Rev. 2007, 87, 1-28. [CrossRef]

153. Windley, S.; Wilhelm, D. Signaling pathways involved in mammalian sex determination and gonad development. Sex. Dev. 2016, 9, 297-315. [CrossRef] [PubMed]

154. Franco, H.L.; Yao, H.H. Sex and hedgehog: Roles of genes in the hedgehog signaling pathway in mammalian sexual differentiation. Chromosome Res. 2012, 20, 247-258. [CrossRef]

155. Barsoum, I.; Yao, H.H. Redundant and differential roles of transcription factors Gli1 and Gli2 in the development of mouse fetal leydig cells. Biol. Reprod. 2011, 84, 894-899. [CrossRef] [PubMed]

156. Bitgood, M.J.; Shen, L.; McMahon, A.P. Sertoli cell signaling by Desert hedgehog regulates the male germline. Curr. Biol. 1996, 6, 298-304. [CrossRef]

157. Park, S.Y.; Tong, M.; Jameson, J. Distinct roles for steroidogenic factor 1 and desert hedgehog pathways in fetal and adult leydig cell development. Endocrinology 2007, 148, 3704-3710. [CrossRef]

158. Brennan, J.; Tilmann, C.; Capel, B. Pdgfr-alpha mediates testis cord organization and fetal Leydig cell development in the XY gonad. Genes Dev. 2003, 17, 800-810. [CrossRef] [PubMed]

159. Smith, C.; McClive, P.J.; Hudson, Q.; Sinclair, A.H. Male-specific cell migration into the developing gonad is a conserved process involving PDGF signalling. Dev. Biol. 2005, 284, 337-350. [CrossRef]

160. Jeays-Ward, K.; Hoyle, C.; Brennan, J.; Dandonneau, M.; Alldus, G.; Capel, B.; Swain, A. Endothelial and steroidogenic cell migration are regulated by WNT4 in the developing mammalian gonad. Development 2003, 130, 3663-3670. [CrossRef] [PubMed]

161. Yao, H.-C.H.; Matzuk, M.M.; Jorgez, C.J.; Menke, D.; Page, D.C.; Swain, A.; Capel, B. Follistatin operates downstream ofWnt4 in mammalian ovary organogenesis. Dev. Dyn. 2004, 230, 210-215. [CrossRef] [PubMed]

162. Thommes, R.C. Vasculogenesis in Selected Endocrine Glnads of Normal and Hypothesectomized Chick Embryos. PhD Thesis, Northwestern University, Evanston, IL, USA; pp. 1-500.

163. Gonzalez-Moran, M.G.; Soria-Castro, E. Histological and stereological studies on Leydig cells in the testes of Gallus do-mesticus from pre-hatching to sexual maturity. Anim. Reprod. Sci. 2010, 120, 129-135. [CrossRef]

164. Haffen, K. Sex differentiation of avian gonads in vitro. Am. Zoöl. 1975, 15, 257-272. [CrossRef]

165. Hassanzadeh, B.; Nabipour, A.; Rassouli, M.B.; Dehghani, H. Morphological development of testes in ostrich (Struthio camelus) embryo. Anat. Sci. Int. 2013, 89, 129-139. [CrossRef]

166. Chen, M.; Zhang, L.; Cui, X.; Lin, X.; Li, Y.; Wang, Y.; Wang, Y.; Qin, Y.; Chen, D.; Han, C.; et al. Wt1 directs the lineage specification of sertoli and granulosa cells by repressing Sf1 expression. Development 2016, 144, 44-53. [CrossRef] [PubMed]

167. Zhang, L.; Chen, M.; Wen, Q.; Li, Y.; Wang, Y.; Wang, Y.; Qin, Y.; Cui, X.; Yang, L.; Huff, V.; et al. Reprogramming of Sertoli cells to fetal-like Leydig cells by Wt1 ablation. Proc. Natl. Acad. Sci. USA 2015, 112, 4003-4008. [CrossRef] [PubMed]

168. Merchant-Larios, H.; Moreno-Mendoza, N. Mesonephric stromal cells differentiate into leydig cells in the mouse fetal testis. Exp. Cell Res. 1998, 244, 230-238. [CrossRef] [PubMed]

169. Estermann, M.A.; Major, A.T.; Smith, C.A. Gonadal sex differentiation: Supporting versus steroidogenic cell lineage specification in mammals and birds. Front. Cell Dev. Biol. 2020, 8. [CrossRef]

170. Lambeth, L.S.; Morris, K.; Ayers, K.L.; Wise, T.G.; O'Neil, T.; Wilson, S.; Cao, Y.; Sinclair, A.H.; Cutting, A.D.; Doran, T.J.; et al. Overexpression of anti-mullerian hormone disrupts gonadal sex differentiation, blocks sex hormone synthesis, and supports cell autonomous sex development in the chicken. Endocrinology 2016, 157, 1258-1275. [CrossRef] [PubMed]

171. Archambeault, D.R.; Yao, H.-C.H. Activin A, a product of fetal Leydig cells, is a unique paracrine regulator of Sertoli cell proliferation and fetal testis cord expansion. Proc. Natl. Acad. Sci. USA 2010, 107, 10526-10531. [CrossRef] [PubMed] 
172. Vaillant, S.; Dorizzi, M.; Pieau, C.; Richard-Mercier, N. Sex reversal and aromatase in chicken. J. Exp. Zoöl. 2001, 290, 727-740. [CrossRef] [PubMed]

173. Ayers, K.; Sinclair, A.; Smith, C. The molecular genetics of ovarian differentiation in the avian model. Sex. Dev. 2013, 7, 80-94. [CrossRef]

174. Woods, J.E.; Podczaski, E.S. Androgen synthesis in the gonads of the chick embryo. Gen. Comp. Endocrinol. 1974, $24,413-423$. [CrossRef]

175. Groenendijk-Huijbers, M.M.; Van Schaik, J.P. Effects of hemicastration, testis implantation and administration of tes-tosterone propionate on the female embryonic genital tract in various breeds and strains of chickens. Verh. Anat. Ges. 1976, 70, 179-182.

176. Woods, J.E.; Simpson, R.M.; Moore, P.L. Plasma testosterone levels in the chick embryo. Gen. Comp. Endocrinol. 1975, 27, 543-547. [CrossRef]

177. Weissmann, A.; Reitemeier, S.; Hahn, A.; Gottschalk, J.; Einspanier, A. Sexing domestic chicken before hatch: A new method for in ovo gender identification. Theriogenology 2013, 80, 199-205. [CrossRef] [PubMed]

178. Tanabe, Y.; Saito, N.; Nakamura, T. Ontogenetic steroidogenesis by testes, ovary, and adrenals of embryonic and postembryonic chickens (Gallus domesticus). Gen. Comp. Endocrinol. 1986, 63, 456-463. [CrossRef]

179. Woods, J.E.; Thommes, R.C. Ontogeny of hypothalamo-adenohypophyseal-gonadal (HAG) interrelationships in the chick embryo. J. Exp. Zoöl. 1984, 232, 435-441. [CrossRef]

180. Woods, J.E.; Podczaski, E.S.; Erton, L.H.; Rutherford, J.E.; McCarter, C.F. Establishment of the adenohypophyseal-testicular axis in the chick embryo I. Testicular androgen levels. Gen. Comp. Endocrinol. 1977, 32, 390-394. [CrossRef]

181. Woods, J.E.; Honan, M.P.; Thommes, R.C. Hypothalamic regulation of the adenohypophyseal-testicular axis in the male chick embryo. Gen. Comp. Endocrinol. 1989, 74, 167-172. [CrossRef]

182. Woods, J.E.; Weeks, R.L. Ontogenesis of the pituitary-gonadal axis in the chick embryo. Gen. Comp. Endocrinol. 1969, 13, $242-254$. [CrossRef]

183. Rios-Rojas, C.; Bowles, J.; Koopman, P. On the role of germ cells in mammalian gonad development: Quiet passengers or back-seat drivers? Reproduction 2015, 149, R181-R191. [CrossRef] [PubMed]

184. Spiller, C.; Koopman, P.; Bowles, J. Sex determination in the mammalian germline. Annu. Rev. Genet. 2017, 51, 265-285. [CrossRef]

185. Bowles, J.; Knight, D.; Smith, C.; Wilhelm, D.; Richman, J.; Mamiya, S.; Yashiro, K.; Chawengsaksophak, K.; Wilson, M.J.; Rossant, J.; et al. Retinoid signaling determines germ cell fate in mice. Science 2006, 312, 596-600. [CrossRef]

186. Koubova, J.; Menke, D.; Zhou, Q.; Capel, B.; Griswold, M.D.; Page, D.C. Retinoic acid regulates sex-specific timing of meiotic initiation in mice. Proc. Natl. Acad. Sci. USA 2006, 103, 2474-2479. [CrossRef] [PubMed]

187. Vernet, N.; Condrea, D.; Mayere, C.; Féret, B.; Klopfenstein, M.; Magnant, W.; Alunni, V.; Telentin, M.; Souali-Crespo, S.; Nef, S.; et al. Meiosis occurs normally in the fetal ovary of mice lacking all retinoic acid receptors. Sci. Adv. 2020, 6, eaaz1139. [CrossRef] [PubMed]

188. Chassot, A.-A.; Le Rolle, M.; Jolivet, G.; Stevant, I.; Guigonis, J.-M.; Da Silva, F.; Nef, S.; Pailhoux, E.; Schedl, A.; Ghyselinck, N.B.; et al. Retinoic acid synthesis by ALDH1A proteins is dispensable for meiosis initiation in the mouse fetal ovary. Sci. Adv. 2020, 6, eaaz1261. [CrossRef] [PubMed]

189. Smith, C.A.; Roeszler, K.N.; Bowles, J.; Koopman, P.; Sinclair, A.H. Onset of meiosis in the chicken embryo; evidence of a role for retinoic acid. BMC Dev. Biol. 2008, 8, 1-9. [CrossRef]

190. Bowles, J.; Feng, C.-W.; Ineson, J.; Miles, K.; Spiller, C.; Harley, V.; Sinclair, A.; Koopman, P. Retinoic acid antagonizes testis development in mice. Cell Rep. 2018, 24, 1330-1341. [CrossRef] [PubMed]

191. Zuo, Q.; Jin, J.; Jin, K.; Sun, C.; Song, J.; Zhang, Y.; Chen, G.; Li, B. Distinct roles of retinoic acid and BMP4 pathways in the formation of chicken primordial germ cells and spermatogonial stem cells. Food Funct. 2019, 10, 7152-7163. [CrossRef] [PubMed]

192. Kim, Y.M.; Han, J.Y. The early development of germ cells in chicken. Int. J. Dev. Biol. 2018, 62, 145-152. [CrossRef]

193. Yu, M.; Yu, P.; Leghari, I.H.; Ge, C.; Mi, Y.; Zhang, C. RALDH2, the enzyme for retinoic acid synthesis, mediates meiosis initiation in germ cells of the female embryonic chickens. Amino Acids 2012, 44, 405-412. [CrossRef]

194. Yousefi Taemeh, S.; Mahdavi Shahri, N.; Lari, R.; Bahrami, A.R.; Dehghani, H. Meiotic initiation in chicken germ cells is regulated by Cyp26b1 and mesonephros. J. Exp. Zool. Part B 2019, 332, 269-278. [CrossRef] [PubMed]

195. Yu, M.; Ge, C.; Zeng, W.; Mi, Y.; Zhang, C. Retinoic acid promotes proliferation of chicken primordial germ cells via activation of PI3K/Akt-mediated NF-kappaB signalling cascade. Cell Biol. Int. 2012, 36, 705-712. [CrossRef] [PubMed]

196. Yang, S.Y.; Lee, H.J.; Lee, H.C.; Hwang, Y.S.; Park, Y.H.; Ono, T.; Han, J.Y. The dynamic development of germ cells during chicken embryogenesis. Poult. Sci. 2018, 97, 650-657. [CrossRef] [PubMed]

197. Nakamura, Y.; Yamamoto, Y.; Usui, F.; Mushika, T.; Ono, T.; Setioko, A.R.; Takeda, K.; Nirasawa, K.; Kagami, H.; Tagami, T. Migration and proliferation of primordial germ cells in the early chicken embryo. Poult. Sci. 2007, 86, 2182-2193. [CrossRef] [PubMed]

198. Mendis, S.H.; Meachem, S.J.; Sarraj, M.A.; Loveland, K.L. Activin a balances sertoli and germ cell proliferation in the fetal mouse testis. Biol. Reprod. 2010, 84, 379-391. [CrossRef]

199. Young, J.C.; Wakitani, S.; Loveland, K.L. TGF-beta superfamily signaling in testis formation and early male germline de-velopment. Semin. Cell Dev. Biol. 2015, 45, 94-103. [CrossRef]

200. Tagami, T.; Miyahara, D.; Nakamura, Y. Avian primordial germ cells. Avian Reprod. 2017, 1001, 1-18. [CrossRef] 
201. Green, C.D.; Ma, Q.; Manske, G.L.; Shami, A.N.; Zheng, X.; Marini, S.; Moritz, L.; Sultan, C.; Gurczynski, S.J.; Moore, B.; et al. A Comprehensive roadmap of murine spermatogenesis defined by single-cell RNA-Seq. Dev. Cell 2018, 46, 651-667. [CrossRef]

202. Chen, Y.; Zheng, Y.; Gao, Y.; Lin, Z.; Yang, S.; Wang, T.; Wang, Q.; Xie, N.; Hua, R.; Liu, M.; et al. Single-cell RNA-seq uncovers dynamic processes and critical regulators in mouse spermatogenesis. Cell Res. 2018, 28, 879-896. [CrossRef] [PubMed]

203. Jeanes, A.; Wilhelm, D.; Wilson, M.J.; Bowles, J.; McClive, P.J.; Sinclair, A.H.; Koopman, P. Evaluation of candidate markers for the peritubular myoid cell lineage in the developing mouse testis. Reproduction 2005, 130, 509-516. [CrossRef]

204. Rebourcet, D.; O'Shaughnessy, P.J.; Pitetti, J.-L.; Monteiro, A.; O'Hara, L.; Milne, L.; Tsai, Y.T.; Cruickshanks, L.; Riethmacher, D.; Guillou, F.; et al. Sertoli cells control peritubular myoid cell fate and support adult Leydig cell development in the prepubertal testis. Development 2014, 141, 2139-2149. [CrossRef]

205. Lei, N.; Heckert, L.L. Gata4 Regulates Testis Expression of DMRT1. Mol. Cell. Biol. 2004, 24, 377-388. [CrossRef]

206. Lei, N.; Heckert, L.L. Sp1 and Egr1 Regulate Transcription of the DMRT1 Gene in Sertoli Cells1. Biol. Reprod. 2002, 66, 675-684. [CrossRef]

207. Ellis, H.L.; Shioda, K.; Rosenthal, N.F.; Coser, K.R.; Shioda, T. Masculine epigenetic sex marks of the CYP19A1/aromatase promoter in genetically male chicken embryonic gonads are resistant to estrogen-induced phenotypic sex conversion. Biol. Reprod. 2012, 87, 23. [CrossRef] [PubMed]

208. Ge, C.; Ye, J.; Weber, C.; Sun, W.; Zhang, H.; Zhou, Y.; Cai, C.; Qian, G.; Capel, B. The histone demethylase KDM6B regulates temperature-dependent sex determination in a turtle species. Science 2018, 360, 645-648. [CrossRef]

209. Davey, M.G.; Balic, A.; Rainger, J.; Sang, H.M.; McGrew, M.J. Illuminating the chicken model through genetic modification. Int. J. Dev. Biol. 2018, 62, 257-264. [CrossRef]

210. Macdonald, J.; Taylor, L.; Sherman, A.; Kawakami, K.; Takahashi, Y.; Sang, H.M.; McGrew, M.J. Efficient genetic modification and germ-line transmission of primordial germ cells using piggyBac and Tol2 transposons. Proc. Natl. Acad. Sci. USA 2012, 109, E1466-E1472. [CrossRef] [PubMed]

211. McGrew, M.J.; Sherman, A.; Ellard, F.M.; Lillico, S.G.; Gilhooley, H.J.; Kingsman, A.J.; Mitrophanous, K.A.; Sang, H. Efficient production of germline transgenic chickens using len-tiviral vectors. EMBO Rep. 2004, 5, 728-733. [CrossRef] [PubMed]

212. Kwon, M.S.; Koo, B.C.; Kim, D.; Nam, Y.H.; Cui, X.-S.; Kim, N.-H.; Kim, T. Generation of transgenic chickens expressing the human erythropoietin (hEPO) gene in an oviduct-specific manner: Production of transgenic chicken eggs containing human erythropoietin in egg whites. PLoS ONE 2018, 13, e0194721. [CrossRef] 